\title{
Heteromeric $\mathrm{K}_{\mathrm{V}} 2 / \mathrm{K}_{\mathrm{V}} 8.2$ Channels Mediate Delayed Rectifier Potassium Currents in Primate Photoreceptors
}

\author{
Jacqueline Gayet-Primo, ${ }^{1}$ Daniel B. Yaeger, ${ }^{3}$ Roupen A. Khanjian, ${ }^{3}$ and $\odot$ Teresa Puthussery ${ }^{1,2,3}$ \\ ${ }^{1}$ School of Optometry, ${ }^{2}$ Helen Wills Neuroscience Institute, University of California, Berkeley, Berkeley, California 94720 , and ${ }^{3}$ Casey Eye Institute, Oregon \\ Health \& Science University, Portland, Oregon 97239
}

\begin{abstract}
Silent voltage-gated potassium channel subunits $\left(\mathrm{K}_{\mathrm{V}} S\right)$ interact selectively with members of the $\mathrm{K}_{\mathrm{V}} 2$ channel family to modify their functional properties. The localization and functional roles of these silent subunits remain poorly understood. Mutations in the $K_{V} S$ subunit, $\mathrm{K}_{\mathrm{V}} 8.2$ (KCNV2), lead to severe visual impairment in humans, but the basis of these deficits remains unclear. Here, we examined the localization, native interactions, and functional properties of $\mathrm{K}_{\mathrm{V}} 8.2$-containing channels in mouse, macaque, and human photoreceptors of either sex. In human retina, $\mathrm{K}_{\mathrm{V}} 8.2$ colocalized with $\mathrm{K}_{\mathrm{V}} 2.1$ and $\mathrm{K}_{\mathrm{V}} 2.2$ in cone inner segments and with $\mathrm{K}_{\mathrm{V}} 2.1$ in rod inner segments. $\mathrm{K}_{\mathrm{V}} 2.1$ and $\mathrm{K}_{\mathrm{V}} 2.2$ could be coimmunoprecipitated with $\mathrm{K}_{\mathrm{V}} 8.2$ in retinal lysates indicating that these subunits likely interact directly. Retinal $\mathrm{K}_{\mathrm{V}} 2.1$ was less phosphorylated than cortical $\mathrm{K}_{\mathrm{V}} 2.1$, a difference expected to alter the biophysical properties of these channels. Using voltage-clamp recordings and pharmacology, we provide functional evidence for Kv2-containing channels in primate rods and cones. We propose that the presence of $\mathrm{K}_{\mathrm{V}} 8.2$, and low levels of $\mathrm{K}_{\mathrm{V}} 2.1$ phosphorylation shift the activation range of $\mathrm{K}_{\mathrm{V}} 2$ channels to align with the operating range of rod and cone photoreceptors. Our data indicate a role for $\mathrm{K}_{\mathrm{V}} 2 / \mathrm{K}_{\mathrm{V}} 8.2$ channels in human photoreceptor function and suggest that the visual deficits in patients with $K C N V 2$ mutations arise from inadequate resting activation of $\mathrm{K}_{\mathrm{V}}$ channels in rod and cone inner segments.
\end{abstract}

Key words: cones; ion channels; potassium channels; retina; rods

\section{Significance Statement}

Mutations in a voltage-gated potassium channel subunit, $\mathrm{K}_{\mathrm{V}} 8.2$, underlie a blinding inherited photoreceptor dystrophy, indicating an important role for these channels in human vision. Here, we have defined the localization and subunit interactions of $\mathrm{K}_{\mathrm{V}} 8.2$ channels in primate photoreceptors. We show that the $\mathrm{K}_{\mathrm{V}} 8.2$ subunit interacts with different Kv2 channels in rods and cones, giving rise to potassium currents with distinct functional properties. Our results provide a molecular basis for retinal dysfunction in patients with mutations in the $K C N V 2$ gene encoding $\mathrm{K}_{\mathrm{V}} 8.2$.

\section{Introduction}

Voltage-gated potassium channels $\left(\mathrm{K}_{\mathrm{V}}\right)$ are a large and diverse family of ion channels expressed in neuronal and non-neuronal tissues. The $\mathrm{K}_{\mathrm{V}} 2$ family (Shab) subunits, $\mathrm{K}_{\mathrm{V}} 2.1$ and $\mathrm{K}_{\mathrm{V}} 2.2$, are high-voltage-activated and are widely expressed in central neurons where they generate delayed rectifier $\mathrm{K}_{\mathrm{V}}$ currents that regu-

Received Aug. 25, 2017; revised Jan. 18, 2018; accepted Feb. 11, 2018.

Author contributions: D.B.Y., R.A.K., and T.P. edited the paper; T.P. wrote the first draft of the paper; J.G.-P., D.B.Y., and T.P. designed research; J.G.-P., D.B.Y., and T.P. performed research; J.G.-P., D.B.Y., R.A.K., and T.P. analyzed data; T.P. wrote the paper.

This study was supported by National Institutes of Health Grants EY024265 to T.P., P30 EY010572 and T32 EY23211 to Oregon Health \& Science University, P510D011092 to Oregon National Primate Research Center, and P30 EY003176 to University of California, Berkeley. We thank Dr. Rowland Taylor for helpful feedback on the manuscript; and Drs. John $\mathrm{Ng}$ and David Wilson (Oregon Health \& Science University) for providing human retinal samples.

The authors declare no competing financial interests.

Correspondence should be addressed to Dr. Teresa Puthussery, School of Optometry \& Helen Wills Neuroscience Institute, 406 Minor Hall, University of California, Berkeley, Berkeley, CA 94720. E-mail: tputhussery@berkeley.edu. DOI:10.1523/JNEUROSCI.2440-17.2018

Copyright $\odot 2018$ the authors $\quad 0270-6474 / 18 / 383414-14 \$ 15.00 / 0$ late the rate and repolarization of action potentials (Liu and Bean, 2014; Kimm et al., 2015). The $\mathrm{K}_{\mathrm{V}} 2$ subunits can only form functional heterotetramers within the $\mathrm{K}_{\mathrm{V}} 2$ family, or with the socalled "modifier/silent" subunits, $\mathrm{K}_{\mathrm{V}} 5, \mathrm{~K}_{\mathrm{V}} 6, \mathrm{~K}_{\mathrm{V}} 8$, and $\mathrm{K}_{\mathrm{V}} 9\left(\mathrm{~K}_{\mathrm{V}} \mathrm{S}\right)$. $\mathrm{K}_{\mathrm{V}} \mathrm{S}$ subunits cannot form functional homomeric channels but interact with $\mathrm{K}_{\mathrm{V}} 2$ channels to alter their biophysical properties (for review, see Bocksteins and Snyders, 2012; Bocksteins, 2016). The $\mathrm{K}_{\mathrm{V}} \mathrm{S}$ subunits are presumed to produce tissue-specific or cell-type-specific modification of $\mathrm{K}_{\mathrm{V}} 2$ channel gating properties; however, the localization, subunit interactions, and functional significance of $\mathrm{K}_{\mathrm{V}} \mathrm{S}$ subunits remain poorly understood.

$\mathrm{K}_{\mathrm{V}} 8.2$ is the only silent subunit that has thus far been implicated in human disease. Variants/mutations in the gene that encodes this protein, KCNV2, have been implicated in epilepsy susceptibility (Jorge et al., 2011), as well as in an inherited photoreceptor dystrophy known as "cone-dystrophy with supernormal rod response” (Wu et al., 2006; Wissinger et al., 2008, 2011; Zelinger et al., 2013). The photoreceptor dystrophy causes re- 
duced visual acuity, photophobia, color vision deficits, and variable loss of night vision (Gouras et al., 1983). Because $\mathrm{K}_{\mathrm{V}} 8.2$ subunits cannot form functional homomeric channels, visual dysfunction presumably arises from alterations in $\mathrm{K}_{\mathrm{V}} 2 / \mathrm{K}_{\mathrm{V}} 8.2$ heteromeric channels. Indeed, in expression systems, $\mathrm{K}_{\mathrm{V}} 2.1 / \mathrm{K}_{\mathrm{V}} 8.2$ heteromers exhibit more hyperpolarized activation potentials, show less inactivation, and have lower current densities than homomeric $K_{V} 2.1$ channels (Czirják et al., 2007; Smith et al., 2012). Although $K_{V} 2.1$ and $K_{V} 8.2$ genes are expressed in human and rodent outer retina (Wu et al., 2006; Czirják et al., 2007), the localization of the proteins remains unclear (Pinto and Klumpp, 1998; Aslanidis et al., 2014). Moreover, to our knowledge, interactions between $K_{V} 2$ and $K_{V} 8.2$ subunits have not yet been demonstrated in any native tissue.

Delayed rectifier $\mathrm{K}_{\mathrm{V}}$ currents are continuously active in photoreceptors. In darkness, photoreceptors are tonically depolarized by a "dark current" mediated by cGMP-gated cation channels in the outer segment. This inward dark current is balanced by a noninactivating delayed rectifier $\mathrm{K}_{\mathrm{V}}$ current in the inner segment, dubbed $\mathrm{I}_{\mathrm{Kx}}$ (Beech and Barnes, 1989; Yan and Matthews, 1992), which stabilizes the resting potential at $\sim-40 \mathrm{mV}$ (Schneeweis and Schnapf, 1995). Upon light stimulation, the photoreceptors hyperpolarize and the $\mathrm{K}_{\mathrm{V}}$ current shuts off with some delay, leading to a delayed depolarizing phase that renders the photoreceptor voltage response more transient and bandpass filtered. The molecular identity of the channels that mediate the delayed rectifier $\mathrm{K}_{\mathrm{V}}$ current has not been resolved. Here, we demonstrate the differential expression of $\mathrm{K}_{\mathrm{V}} 2.1, \mathrm{~K}_{\mathrm{V}} 2.2$, and $\mathrm{K}_{\mathrm{V}} 8.2$ in rod and cone photoreceptors in human and mouse retina, show proteinbinding interactions between these $\mathrm{K}$ channel subunits in the retina, and provide physiological and pharmacological evidence that there are functional Kv2-containing channels in nonhuman primate photoreceptors. Our results provide insights into the molecular basis for visual deficits in patients with KCNV2 mutations.

\section{Materials and Methods}

Tissue preparation. Human retinal samples were obtained from eyes that were enucleated for management of lid or orbital tumors, but there was no significant coexisting retinal pathology. Samples were deidentified before receipt by the investigators of this study, and thus the Oregon Health \& Science University Institutional Review Board deemed use of these tissues "nonhuman subject research." Nonhuman primate eyes were obtained from adult rhesus or cynomolgus macaques of either sex. Eyes were recovered from animals killed in the course of unrelated experiments, through the Tissue Distribution Program at the Oregon National Primate Research Center, Oregon Health \& Science University. The anterior eye, lens, and vitreous were removed, and the retina, with attached pigment epithelium and choroid, was removed from the sclera. Tissue was maintained in Ames' medium equilibrated with $95 \% \mathrm{O}_{2} / 5 \%$ $\mathrm{CO}_{2}$ at $\sim 25^{\circ} \mathrm{C}$. For immunohistochemistry, retinae were fixed with pigment attached for 5-30 min in 4\% PFA in $0.1 \mathrm{~m} \mathrm{~PB}$. Adult ( $>4$ weeks) C57BL/6J wild-type mice of either sex were killed by an intraperitoneal overdose of sodium pentobarbital or by cervical dislocation. All mouse procedures were approved by the Oregon Health \& Science University Institutional Animal Care and Use Committee. For immunoprecipitation and immunoblots, macaque retinae were isolated in Ames' medium, snap frozen on liquid nitrogen, and stored at $-80^{\circ} \mathrm{C}$ until further use.

Immunohistochemistry. Details of the primary antibodies used in this study are given in Table 1. Indirect immunofluorescence immunohistochemistry was performed essentially as described previously (Puthussery et al., 2011, 2013). Briefly, pieces of retina with attached RPE/choroid (human and macaque) or posterior eyecups (mouse) were cryoprotected in graded sucrose solutions (10-30\%), embedded in Cryogel mounting medium, and sectioned at $14 \mu \mathrm{m}$. For mouse retinal sections, slices tra- versed the dorsal to ventral retina to rule out any staining variations that might arise due to differences in cone distribution. Mouse eyes were oriented using previously described protocols (Wei et al., 2010). In some experiments with $\mathrm{K}_{\mathrm{V}} 8.2$ antibodies ( $\mathrm{ms}$ and $\mathrm{rb}$ ), sections were treated for antigen retrieval with $0.15 \mathrm{mg} / \mathrm{ml}$ pepsin in $0.2 \mathrm{M} \mathrm{HCl}$ at $25^{\circ} \mathrm{C}$. The reaction was stopped with washes in ice-cold $0.1 \mathrm{M}$ PB before proceeding to the blocking step. Nonspecific binding sites were blocked in $10 \%$ normal horse serum, $1 \%$ Triton X-100, $0.025 \% \mathrm{NaN}_{3}$ in PBS for $1 \mathrm{~h}$ at $25^{\circ} \mathrm{C}$. Primary antibodies were diluted in $3 \%$ normal horse serum, $1 \%$ Triton X-100, $0.025 \% \mathrm{NaN}_{3}$ in PBS and applied to sections overnight at $25^{\circ} \mathrm{C}$. After washing, sections were incubated in secondary antibodies diluted in $3 \%$ normal horse serum, $0.025 \% \mathrm{NaN}_{3}$ in PBS for $1 \mathrm{~h}$ at $25^{\circ} \mathrm{C}$. Secondary antibodies were raised in donkey or goat and conjugated to AlexaFluor-488, -594, or -647 (Invitrogen) or Cy3 (Jackson ImmunoResearch Laboratories). Isotype selective anti-mouse secondary antibodies were used when mouse monoclonal antibodies of different IgG subclasses were combined in double labeling experiments. In some experiments, we used AlexaFluor-488-conjugated peanut agglutinin (PNA) lectin to localize mouse cones (Invitrogen, L21409). Slides were mounted in Mowiol mounting medium.

Confocal images were acquired on an Olympus FV1000 laser scanning microscope $(60 \times / 1.4$ objective, 488,559 , and $643 \mathrm{~nm}$ laser lines $)$ or on a Zeiss LSM 880 laser scanning microscope $(63 \times / 1.4$ objective, 488,561 , and $594 \mathrm{~nm}$ laser lines). Images were acquired sequentially to prevent fluorescent cross talk. In some cases, adjustments to image brightness and contrast were made with ImageJ (Fiji) 1.48r or Adobe Photoshop CC.

For quantification of $\mathrm{K}_{\mathrm{V}} 2$ staining intensity in human cones, we acquired confocal $z$ stacks of vertical sections of retina labeled for $\mathrm{K}_{\mathrm{V}} 2.2$ and $\mathrm{S}$ cone-opsin. Optimal PMT gain and laser power settings were determined while viewing a high-low lookup table to prevent pixel saturation. Acquisition settings were then kept constant for imaging different regions from the same sample. Confocal image stacks were analyzed using Fiji. For each cone, we found the central plane of the inner segment and then made 10 straight line profile plots ( 10 pixel width) perpendicular to the membrane. The peaks of the intensity plots were then aligned and averaged together in Igor Pro 6.0 (Wavemetrics) to find the average membrane intensity for each cone inner segment. Data were analyzed using paired $t$ tests with an $\alpha$ value of 0.05 .

Immunoblots and immunoprecipitation. For immunoprecipitation and immunoblotting experiments of macaque retina, tissues were either snap frozen at $-80^{\circ} \mathrm{C}$ or solubilized in a lysis buffer containing $50 \mathrm{~mm}$ Tris, $\mathrm{pH}$ 7.5, $150 \mathrm{~mm} \mathrm{NaCl}, 5 \mathrm{~mm}$ EDTA $1 \%$ Triton X-100, and $1 \times$ protease and phosphatase inhibitor mixture (Thermo Scientific, catalog \#78440) for $1 \mathrm{~h}$ with periodic mixing and frozen at $-80^{\circ} \mathrm{C}$ until further use. Protein concentration was determined using the BCA Protein Assay (Thermo Scientific). For immunoprecipitation, retinal lysates were precleared on Pierce Control Resin for $60 \mathrm{~min}$ at $4^{\circ} \mathrm{C}$, then processed using the indirect method. Capture antibodies were added to lysates at a concentration of $2-11.25 \mu \mathrm{g} / \mathrm{ml}$, and samples were incubated for $2 \mathrm{~h}$ at $4^{\circ} \mathrm{C}$ with mixing. Protein A/G-coated agarose beads (Pierce) were then added to the lysates and left overnight at $4^{\circ} \mathrm{C}$ with mixing. Beads were collected by centrifugation, washed 6-8 times in lysis buffer, and bound proteins were eluted by adding Novex Tris-glycine SDS sample buffer with $2.5 \%$ $\beta$-mercaptoethanol or $100 \mathrm{~mm}$ DTT. Eluates were heated to $85^{\circ} \mathrm{C}$ for 5 min, separated by SDS-PAGE on Novex $4 \%-20 \%$ Tris-glycine gels, then transferred to nitrocellulose membranes. To ensure reproducibility, coimmunoprecipitation assays were replicated in 2-5 independent experiments with tissues from different animals.

For immunoblotting, membranes were blocked for $1 \mathrm{~h}$ in Odyssey Blocking Buffer (Li-Cor Biosciences). Primary antibodies (anti- $\mathrm{K}_{\mathrm{V}} 2.1$ clone $\mathrm{K} 89 / 34$, anti- $\mathrm{K}_{\mathrm{V}} 2.2$ clone $\mathrm{N} 372 \mathrm{~B} / 1$, rabbit anti- $\mathrm{K}_{\mathrm{V}} 8.2$ ) were diluted in the same buffer and applied for $2 \mathrm{~h}$ at $25^{\circ} \mathrm{C}$ or overnight at $4^{\circ} \mathrm{C}$. The membrane was washed extensively in PBS-Tween-20 before incubating for $30 \mathrm{~min}$ at $25^{\circ} \mathrm{C}$ with the appropriate infrared dye-conjugated secondary antibodies (goat anti-mouse IgG IRDye 800CW, 1:7500, Li-Cor Biosciences or goat anti-rabbit Alexa-680, 1:7500, Invitrogen) diluted in Odyssey Blocking Buffer. Infrared secondary antibodies were visualized 
Table 1. Primary antibody information ${ }^{a}$

\begin{tabular}{|c|c|c|c|c|c|}
\hline Antibody & Host/isotype & Immunogen & Supplier/catalog \#/lot \#/RRID \# & Validation & Dilution and application \\
\hline Calbindin & Rabbit & Recombinant rat calbindin D-28k & $\begin{array}{l}\text { Swant, Switzerland, catalog \#CB38, } \\
\text { RRID:AB_10000340 }\end{array}$ & $\begin{array}{l}\text { Immunostaining in cerebellum of calbindin } \\
\text { D-28k K0 mouse (see datasheet) }\end{array}$ & IHC: 1:8000 \\
\hline $\begin{array}{l}\text { Glutamine } \\
\text { synthetase }\end{array}$ & Mouse $\lg _{2 \mathrm{a}}$ & $\begin{array}{l}\text { Human glutamine synthetase a.a. } \\
\qquad 1-373\end{array}$ & $\begin{array}{l}\text { BD Biosciences, catalog \#610517, } \\
\text { RRID: AB_397879 }\end{array}$ & $\begin{array}{l}\text { Recognizes a } 45 \mathrm{kDa} \text { band on WBs of rat } \\
\text { cerebrum lysates (see datasheet); } \\
\text { expected pattern of staining in Müller glia }\end{array}$ & IHC: $1: 10,000$ \\
\hline KV $2.1(K 89 / 34)$ & Mouse $\lg \mathrm{G}_{1}$ & a.a. $837-853$ of rat $K_{v} 2.1$ & $\begin{array}{l}\text { NeuroMab, }{ }^{b} \text { catalog \#75-014, RRID: } \\
\text { AB_10673392, lot \#449-3AK-78 }\end{array}$ & WB in $\mathrm{K}_{\mathrm{v}} 2.1 \mathrm{~K} 0$ mouse (see datasheet) & $\begin{array}{l}\text { IHC: } 1: 800 \\
\text { WB: } 1: 800 \\
\text { IP: } 11.25 \mu \mathrm{g} / \mathrm{ml} \text { protein }\end{array}$ \\
\hline$K_{v} 2.1(L 80 / 21)$ & Mouse $\lg G_{3}$ & a.a. $837-853$ of rat $K_{v} 2.1$ & $\begin{array}{l}\text { NeuroMab, catalog \#73-315 RRID: } \\
\text { AB_2315862, lot \#437-6VA-52 }\end{array}$ & WB in $\mathrm{K}_{\mathrm{v}} 2.1 \mathrm{~K} 0$ mouse (see datasheet) & WB: $1: 10$ \\
\hline$K_{v} 2.2$ & Rabbit & a.a. $859-873$ of rat $K_{v} 2.2$ & $\begin{array}{l}\text { Alomone Labs, catalog \#APC120, } \\
\text { RRID:AB_2040164, lot \#AN-01 }\end{array}$ & $\begin{array}{l}\text { WB with anti-K } 2.2 \text { antibody preincubated } \\
\text { with the control peptide antigen (see } \\
\text { datasheet); tested by immunohistochemistry } \\
\text { in K0 mouse (Tong et al., 2013) }\end{array}$ & $\begin{array}{l}\text { IHC: } 1: 4000 \\
\text { IP: } 11.25 \mu \mathrm{g} / \mathrm{ml} \text { protein }\end{array}$ \\
\hline $\mathrm{K}_{\mathrm{v}} 2.2(\mathrm{~N} 372 \mathrm{~B} / 1)$ & Mouse $\lg \mathrm{G}_{1}$ & $\begin{array}{l}\text { a.a. } 717-907 \text { of rat } \mathrm{K}_{\mathrm{v}} 2.2 \text { long } \\
\text { isoform }\end{array}$ & $\begin{array}{l}\text { NeuroMab, catalog \#73-369, RRID: } \\
\text { AB_2315869, lot \#437-8VA-10 }\end{array}$ & $\begin{array}{l}\text { Immunostaining in } \mathrm{K}_{\mathrm{v}} 2.2 \mathrm{~K} 0 \text { mouse (see } \\
\text { datasheet) }\end{array}$ & $\begin{array}{l}\text { IHC: } 1: 8-1: 10 \\
\text { WB: } 1: 8-1: 10\end{array}$ \\
\hline $\mathrm{K}_{\mathrm{V}} 2.2(\mathrm{~N} 373 \mathrm{~B} / 60)$ & Mouse $\lg G_{2 b}$ & $\begin{array}{l}\text { a.a. } 717-907 \text { of rat } \mathrm{K}_{\mathrm{v}} 2.2 \mathrm{long} \\
\text { isoform }\end{array}$ & $\begin{array}{l}\text { NeuroMab, catalog \#73-360, RRID: } \\
\text { AB_2315867, lot \#437-7VA-76 }\end{array}$ & $\begin{array}{l}\text { WB and immunostaining in } \mathrm{K}_{\mathrm{v}} 2.2 \mathrm{KO} \text { mouse } \\
\text { (see datasheet) }\end{array}$ & IHC: 1:10 \\
\hline $\mathrm{K}_{\mathrm{v}} 2.2(\mathrm{~N} 372 \mathrm{C} / 51)$ & Mouse $\lg \mathrm{G}_{1}$ & $\begin{array}{l}\text { a.a. } 717-907 \text { of rat } \mathrm{K}_{\mathrm{V}} 2.2 \mathrm{long} \\
\text { isoform }\end{array}$ & $\begin{array}{l}\text { NeuroMab, catalog \#73-358, } \\
\text { RRID:AB_2315865, lot \#437-7VA-73 }\end{array}$ & $\begin{array}{l}\text { WB and immunostaining in } \mathrm{K}_{\mathrm{v}} 2.2 \mathrm{KO} \text { mouse } \\
\text { (see datasheet) }\end{array}$ & IHC: 1:10 \\
\hline$K_{v} 2.2(K 37 / 89)$ & Mouse $\lg G_{2 a}$ & a.a. $1-61$ of human $K_{v} 2.2$ & $\begin{array}{l}\text { NeuroMab, catalog \#73-015, } \\
\text { RRID:AB_10673393, lot \#413- } \\
\text { 5RR-08; catalog \#75-015, lot } \\
\text { \#443-1KS-100 }\end{array}$ & WB in $\mathrm{K}_{\mathrm{v}} 2.2 \mathrm{~K} 0$ mouse (see datasheet) & IHC: 1:50 \\
\hline$K_{v} 8.2$ & Mouse $\lg G_{2 b}$ & a.a. $1-163$ of mouse $K_{v} 8.2$ & $\begin{array}{l}\text { NeuroMab, catalog \#73-435, } \\
\text { RRID:AB_2532091, lot \#463- } \\
\text { 1DH-95 }\end{array}$ & $\begin{array}{l}\text { Immunostaining in transfected cells expressing } \\
\text { target and brain immunoblots (see datasheet) }\end{array}$ & IHC: mouse 1:2 \\
\hline$K_{v} 8.2$ & Rabbit & a.a. $16-75$ of human $K_{v} 8.2$ & $\begin{array}{l}\text { Sigma-Aldrich, catalog \#HPA031131, } \\
\text { RRID:AB_10609996, lot } \\
\text { \#R31013 }\end{array}$ & $\begin{array}{l}\text { Validated by protein array, single peak } \\
\text { corresponding to } K_{v} 8.2 \text { antigen, } \\
\text { immunostaining of human pancreas } \\
\text { (see datasheet) }\end{array}$ & $\begin{array}{l}\text { IHC: macaque and human 1:100 } \\
\text { IP: } 11.25 \mu \mathrm{g} / \mathrm{ml} \text { protein }\end{array}$ \\
\hline S-opsin & Goat & $\begin{array}{l}\text { Peptide mapping at the } \mathrm{N} \text {-terminus } \\
\text { of the opsin protein encoded by } \\
\text { OPN1SW of human origin }\end{array}$ & $\begin{array}{l}\text { Santa Cruz Biotechnology, catalog } \\
\text { \#sc-14363, RRID:AB_2158332 }\end{array}$ & $\begin{array}{l}\text { Pattern of staining consistent with expected } \\
\text { ratio of S-cones; no cross-reactivity with } \\
\text { cones expressing L/M opsin }\end{array}$ & IHC: 1:500 \\
\hline L/M opsin & Rabbit & $\begin{array}{l}\text { Recombinant human red/green } \\
\text { opsin }\end{array}$ & $\begin{array}{l}\text { Millipore, catalog \#AB5405, RRID: } \\
\text { AB_11212667, lot \#2618475 }\end{array}$ & $\begin{array}{l}\text { Pattern of staining consistent with expected } \\
\text { ratio of L/M-cones; no cross-reactivity } \\
\text { with cones expressing S opsin }\end{array}$ & IHC: 1:500 \\
\hline
\end{tabular}

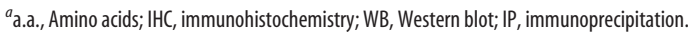

${ }^{b}$ NeuroMab catalog numbers commencing 73 - are tissue culture supernatants.

with an Odyssey Scanner (LI-COR), and digital images were uniformly adjusted for brightness and contrast using Image Studio Lite software (LI-COR Biosciences).

To study the phosphorylation state of $\mathrm{K}_{\mathrm{V}} 2.1$ protein, mice were killed by cervical dislocation, and the retinae and brains were removed within a 1 min postmortem period. Retinae and neocortices were dissected and homogenized in ice-cold homogenization buffer containing the following: $50 \mathrm{~mm}$ Tris, $\mathrm{pH} 7.5,150 \mathrm{~mm} \mathrm{NaCl}, 1 \%$ Triton X-100, $1 \times$ protease, and $1-2 \times$ phosphatase inhibitor mixture (Thermo Scientific, product $\# 1861280$ ). Homogenates were then incubated with 1 unit of calf intestinal alkaline phosphatase (AP, Roche/Sigma-Aldrich\#11 097075 001, 20 $\mathrm{U} / \mathrm{ml}$ ) per $\mu \mathrm{g}$ of protein for $2 \mathrm{~h}$ at $37^{\circ} \mathrm{C}$ or without calf intestinal AP for $2 \mathrm{~h}$ at $4^{\circ} \mathrm{C}$ or $37^{\circ} \mathrm{C}$. To measure the relative electrophoretic shift with AP treatment, we subtracted the molecular weight of the $\mathrm{K}_{\mathrm{V}} 2.1$ band after AP treatment $\left(37^{\circ} \mathrm{C}\right)$ from the weight of the $\mathrm{K}_{\mathrm{V}} 2.1$ band without AP treatment $\left(4^{\circ} \mathrm{C}\right)$. Samples were diluted in a reducing sample buffer $(15 \mu \mathrm{g}$ of crude retina protein or $30 \mu \mathrm{g}$ of cortical protein/lane), separated by SDS-PAGE on Novex $6 \%$ Tris-glycine gels and transferred to nitrocellulose membranes.

Electrophysiology. All tissue dissections and recordings were made under light-adapted conditions. After removal of the sclera, the macaque retina with attached pigment epithelium and choroid was maintained in Ames' medium equilibrated with $95 \% \mathrm{O}_{2} / 5 \% \mathrm{CO}_{2}$ until use. Whole-cell recordings of rod and cone photoreceptors were made either in retinal slices or intact retinal whole mounts. For whole-mount recordings, the choroid was slowly peeled away and the retina was placed photoreceptor side-up in the recording chamber. For slices, isolated retina was mounted ganglion cell side down on nitrocellulose membrane and cut at 300-350 $\mu \mathrm{m}$ with a manual tissue chopper (MyNeuroLab, Leica Microsystems). Slices were mounted vertically on a coverslip between two tracks of vacuum grease. For cone recordings, cells were targeted for patch-clamp recordings at the level of the inner segment, whereas rods were recorded from the soma or inner segment. All recordings were made from retinal pieces $>6 \mathrm{~mm}$ from the foveal center.

Slices were transferred to the recording chamber and continuously superfused with carbogenated Ames' at a rate of $3 \mathrm{ml} / \mathrm{min}$. A temperature controller (Cell Microcontrols) was used to maintain the chamber at $33^{\circ} \mathrm{C}-34^{\circ} \mathrm{C}$. Whole-cell voltage-clamp recordings were obtained with an HEKA EPC10 patch-clamp amplifier on an Olympus BX51WI microscope fitted with infrared Dodt contrast $(850 \mathrm{~nm})$. The following extracellular recordings solutions were used in these studies: (1) Ames' medium (US Biologicals); (2) Co-Cs Ames' medium (in mM as follows): $116 \mathrm{NaCl}, 23 \mathrm{NaHCO}_{3}, 3.1 \mathrm{KCl}, 1.15 \mathrm{CoCl}_{2}, 1.2 \mathrm{MgCl}_{2}, 4 \mathrm{CsCl}, 6$ glucose, $0.5 \mathrm{~L}$-glutamine, and in some experiments (see Fig. 5, 3 cones) $2 \mathrm{~mm}$ 4-AP; and (3) Co-Cs Ames' medium $+5 \mathrm{~mm} \mathrm{BaCl}_{2}$. For all experiments, retinae were maintained in normal Ames' medium between recordings. Shortly before or upon obtaining the whole-cell recording, the perfusion line was switched to Co-Cs Ames' and the bath was equilibrated for $3 \mathrm{~min}$ 

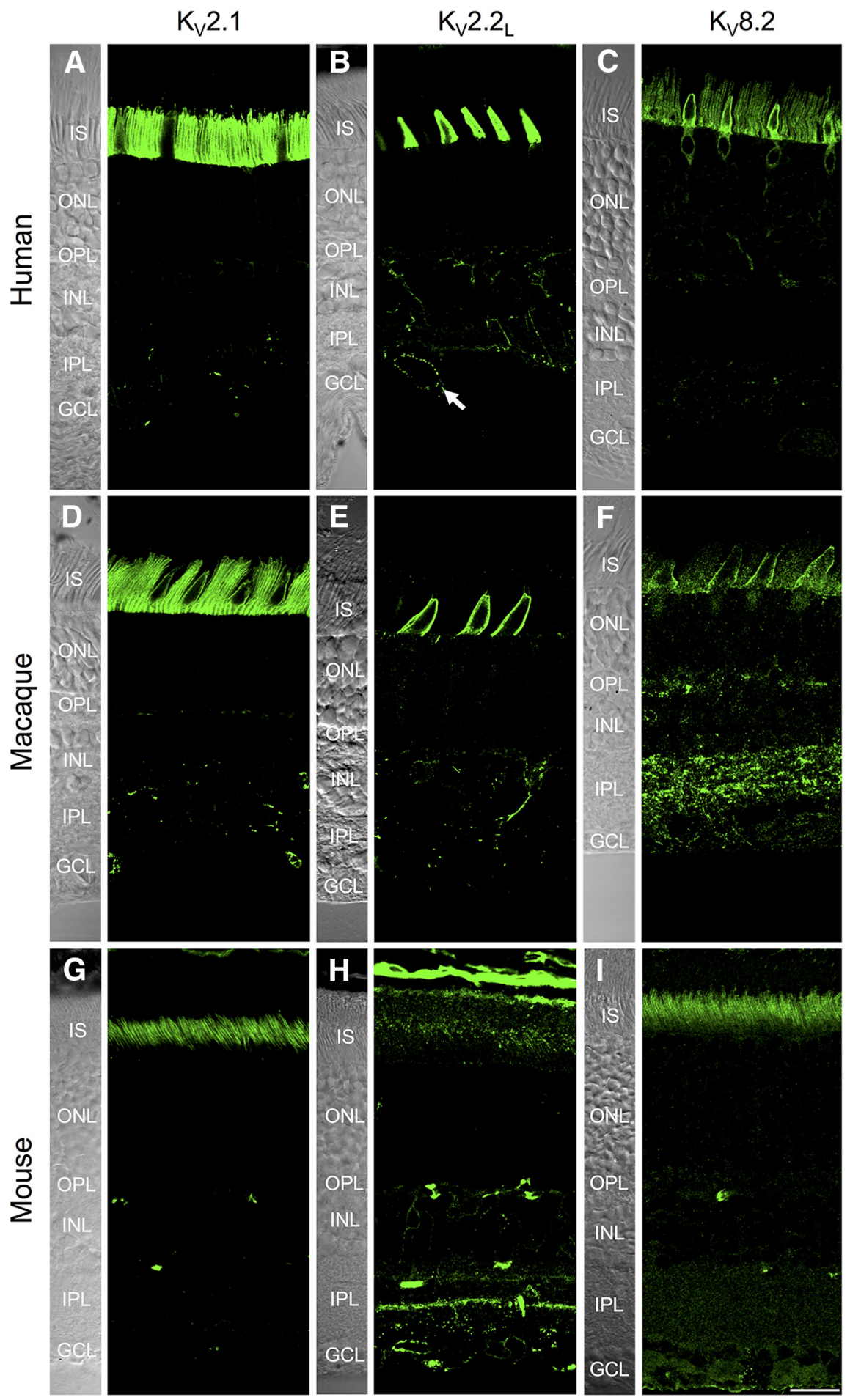

Figure 1. Localization of $K_{v} 2.1, K_{v} 2.2$, and $K_{v} 8.2$ in human, macaque, and mouse retina. Confocal $z$ projections showing immunolocalization of $\mathrm{K}_{\mathrm{v}} 2.1, \mathrm{~K}_{\mathrm{v}} 2.2_{\text {long }}$ and $\mathrm{K}_{\mathrm{v}} 8.2$ in human $(\boldsymbol{A}-\boldsymbol{C})$, macaque $(\boldsymbol{D}-\boldsymbol{F})$, and mouse $(\boldsymbol{G}-\boldsymbol{I})$ retina. In human and macaque retina, strong expression of all channel subunits is evident at the level of the photoreceptor inner segments (IS), but the photoreceptor nuclei and terminals show absent or scant labeling. $\boldsymbol{A}, \boldsymbol{B}$, Intentionally saturated to show the presence of Kv subunits in the inner retina. ONL, Outer nuclear layer; $0 \mathrm{PL}$, outer plexiform layer; INL, inner nuclear layer; IPL, inner plexiform layer; $G C L$, ganglion cell layer. $\boldsymbol{B}$, Arrow indicates clustered membrane labeling in a ganglion cell. Scale bar, $20 \mu \mathrm{m}$.

before commencing recordings of isolated $\mathrm{K}_{\mathrm{V}}$ currents. All control data shown here are from tissues bathed in Co-Cs Ames'. Patch-clamp electrodes $(8-10 \mathrm{M} \Omega)$ were filled with an intracellular solution containing the following (in mM): $118 \mathrm{~K}$-methanesulfonate, $10 \mathrm{KCl}, 2 \mathrm{Mg}$-ATP, 1 Na-GTP, 1 EGTA, $10 \mathrm{Na}$-HEPES, $10 \mathrm{Na}_{2}$-phosphocreatine adjusted to $\mathrm{pH} 7.35$ with $\mathrm{KOH}$. Slices were maintained in normal Ames' medium at room temperature $\left(\sim 25^{\circ} \mathrm{C}\right)$ between recordings. Voltages have been corrected by subtracting a $10 \mathrm{mV}$ liquid-junction potential. Series resistance was compensated online by $30 \%-$ $70 \%$. All experiments were performed at $33^{\circ} \mathrm{C}-34^{\circ} \mathrm{C}$. Guangxitoxin-1E (GxTX-1E) and citalopram were obtained from Alomone Labs and were stored in aliquots at $-20^{\circ} \mathrm{C}$ until use. Stock solutions of GxTX-1E were made up in PBS and stabilized with $0.1 \%$ BSA as carrier. Drug-containing solutions were superfused for at least 3-4 min before postapplication recordings were made. For focal application of GxTX$1 \mathrm{E}$, the peptide toxin was added to Co-Cs Ames' solution to a final concentration of $1 \mu \mathrm{M}$ and pressure applied (Picospritzer, $\sim 3 \mathrm{psi}$ ) via a patch pipette $(8-10 \mathrm{M} \Omega)$ positioned near the photoreceptor inner segment.

Data were analyzed using custom software in Igor Pro 6 and 7 (Wavemetrics). Tail currents were measured at a fixed time point near the peak current $(0.555 \mathrm{~s})$ and were recorded at least 2-3 min after whole-cell dialysis. Activation curves were fitted with a simple Boltzmann equation $\left(\mathrm{f}(\mathrm{V})=\mathrm{G}_{\max } /(1+\exp \right.$ $\left.\left.\left(\left(\mathrm{V}_{1 / 2}-\mathrm{V}\right) / k\right)\right)\right)$ where $\mathrm{V}$ is the membrane potential, $G_{\max }$ is the maximal conductance, $V_{1 / 2}$ is the potential at which half the channels are activated, and $k$ is the voltage-change that produces an e-fold change in channel activity. Current was converted to chord conductance based on a calculated potassium equilibrium potential of $-98 \mathrm{mV}$. Percentage inactivation of the high-voltage-activated $\mathrm{K}_{\mathrm{V}}$ current (see Fig. 7) was calculated from the ratio of the current measured at 480 and $20 \mathrm{~ms}$ after the onset of the voltage step. For experiments where GxTX-1E and citalopram were bath-applied, net voltage-gated currents at each potential were obtained by subtracting linear currents estimated as scaled responses to $10 \mathrm{mV}$ depolarizations delivered from the holding potential. GxTX-1E or citalopram-sensitive currents were calculated by subtracting net voltagegated currents obtained after drug application from currents obtained before drug application. For experiments where GxTX-1E was focally applied (see Fig. 9C), the magnitude of the voltage-gated currents was measured by subtracting the instantaneous current component from the peak current amplitude.

Experimental design and statistics. For immunohistochemistry experiments, we imaged 38 slides from 10 macaques ( 8 females, 2 males, age range $6-22$ years, mean age 11.5 years, median age 11.5 years) and one whole-mount retina. Seventeen sections were immunolabeled with $\mathrm{K}_{\mathrm{V}} 2.1,11$ sections with $\mathrm{K}_{\mathrm{V}} 2.2$, and 15 sections with $\mathrm{K}_{\mathrm{V}} 8.2$. For human retina, we imaged a total of 32 slides from 4 individuals ( 1 female age 41 years, 3 males, ages 61, 71, 72 years) and one retinal whole mount. A total of 25 sections were labeled for $\mathrm{K}_{\mathrm{V}} 2.1$, 10 sections for $\mathrm{K}_{\mathrm{V}} 2.2$, and

15 sections for $\mathrm{K}_{\mathrm{V}} 8.2$. For mouse retina, we imaged 19 slides from 8 animals (either gender, age range 7 weeks to 11 months) and one whole-mount retina. Five sections were labeled for $\mathrm{K}_{\mathrm{V}} 2.1$, 9 sections for $\mathrm{K}_{\mathrm{V}} 2.2$, and 9 sections for $\mathrm{K}_{\mathrm{V}} 8.2$.

We used paired $t$ tests for comparisons where indicated. For nonpaired data, we tested for equal variances using an $F$ test and then 
applied either an unpaired, two-tailed $t$ test (equal variance) or a Welch's $t$ test (unequal variance). Statistical comparisons were made using the Data Analysis add-on of Microsoft Excel. An $\alpha$ level of 0.05 was used for all comparisons.

\section{Results}

Localization of $K_{V} 2$ and $K_{V} 8.2$ subunits in mouse and primate photoreceptors Our first objective was to determine the localization of $\mathrm{K}_{\mathrm{V}} 8.2$ and its interacting subunits. Using immunohistochemistry, we found that $\mathrm{K}_{\mathrm{V}} 8.2, \mathrm{~K}_{\mathrm{V}} 2.1$, and $\mathrm{K}_{\mathrm{V}} 2.2$ were highly expressed in human photoreceptor inner segments (ellipsoid and myoid regions; Fig. $1 A-C$ ) but were absent or scant in the outer segment, nuclear region, and synaptic terminals. Two isoforms of $\mathrm{K}_{\mathrm{V}} 2.2$ have been previously described in the rat brain, $\mathrm{K}_{\mathrm{V}} 2.2_{\text {short }}$ and $\mathrm{K}_{\mathrm{V}} 2.2_{\text {long}}$; the long isoform can form functional heteromers with $\mathrm{K}_{\mathrm{V}} 2.1$, whereas the short isoform cannot (Kihira et al., 2010). Staining with two antibodies specific for $\mathrm{K}_{\mathrm{V}} 2.2_{\text {long }}$ (clone $\mathrm{N} 372 \mathrm{~B} / 1$ and rabbit polyclonal antibody) confirmed expression of $\mathrm{K}_{\mathrm{V}} 2.2_{\text {long }}$ in photoreceptors. A comparable pattern of staining was seen with an antibody that reacts with both the short and long isoforms of $\mathrm{K}_{\mathrm{V}} 2.2$ (clone K37/ 89 ), suggesting that $K_{V} 2.2_{\text {long }}$ is the major retinal isoform $\left(\mathrm{K}_{\mathrm{V}} 2.2_{\text {long-specific anti- }}\right.$ body shown in Fig. $1 B$ ). The $\mathrm{K}_{\mathrm{V}} 2.1$ and $\mathrm{K}_{\mathrm{V}} 2.2$ antibodies also labeled some bipolar, amacrine, and ganglion cells, which we have not examined further here.

To determine to what extent $\mathrm{K}_{\mathrm{V}}$ subunit localization is conserved in photoreceptors of other mammals, we examined $\mathrm{Kv}$ subunit localization in macaque (Fig. $1 D-F$ ) and mouse retina (Fig. $1 G-I$ ). The overall pattern of localization for $\mathrm{K}_{\mathrm{V}} 2.1$ and $\mathrm{K}_{\mathrm{V}} 2.2$ was comparable between macaque and human retina. $\mathrm{K}_{\mathrm{V}} 8.2 \mathrm{immu-}$ nolabeling was more robust in human photoreceptors than in macaque retina, a difference that may be attributable to the fact that that the antigen used to generate the rabbit-anti- $\mathrm{K}_{\mathrm{V}} 8.2$ antibody showed lower homology with the macaque $K_{\mathrm{V}} 8.2$ sequence (predicted homology $\sim 91 \%$ ) than with the human $\mathrm{K}_{\mathrm{V}} 8.2$ sequence $(100 \%)$. As in primate retina, $\mathrm{K}_{\mathrm{V}} 2.1$ and $\mathrm{K}_{\mathrm{V}} 8.2$ were expressed in mouse photoreceptors, but $\mathrm{K}_{\mathrm{V}} 2.2$ was not detectable. To verify this apparent species difference between mouse and primate, we tested five different antibodies raised against three unique epitopes of $\mathrm{K}_{\mathrm{V}} 2.2$, all of which have been validated for specificity in knock-out mice (see Table 1). In mouse and rat retina, all of the $\mathrm{K}_{\mathrm{V}} 2.2$ antibodies labeled inner retinal neurons, but not photoreceptors $\left(\mathrm{K}_{\mathrm{V}} 2.2_{\mathrm{L}}\right.$ clone $\mathrm{N} 372 \mathrm{~B} / 1 \mathrm{AB}$ shown in Fig. 1; other data not shown). Interestingly, $\mathrm{K}_{\mathrm{V}} 2.2$ was expressed in rabbit photoreceptors (data not shown), similar to in primate retina. Together, these data indicate that $\mathrm{K}_{\mathrm{V}} 2.1$ and fiber layer.
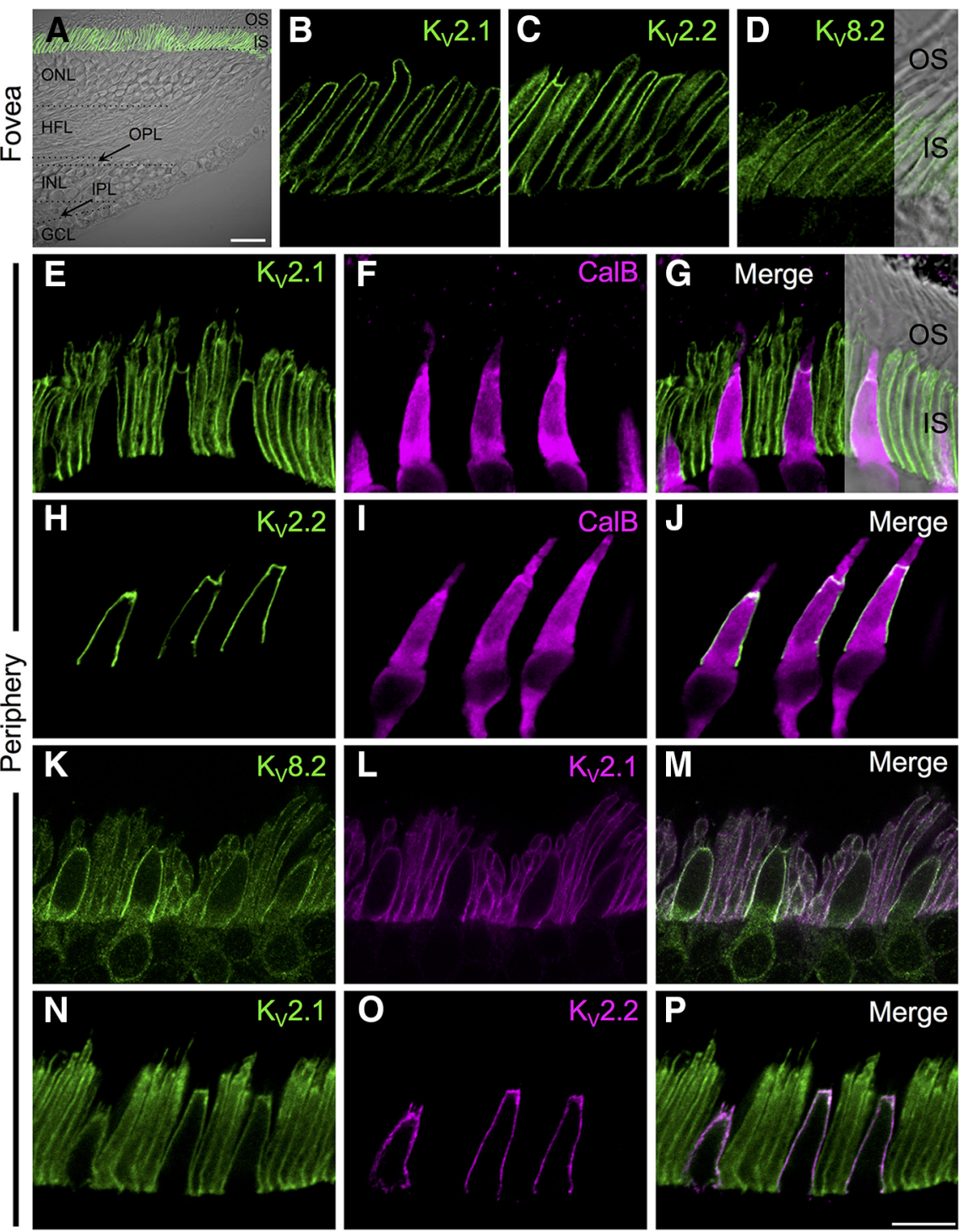

Figure 2. Differential expression of $K_{v} 2$ channel subunits in human rods and cones. $A$, Low-power confocal micrograph showing a transmitted light view of the human foveal slope overlaid on immunostaining for $K_{\mathrm{V}} 2.1$ (green). $\boldsymbol{B}-\boldsymbol{D}$, Localization of $\mathrm{K}_{\mathrm{v}} 2.1$, $K_{v} 2.2$, and $K_{v} 8.2$ in foveal cone inner segment membranes within the central rod-free zone. $K_{v} 2.1$ and $K_{v} 2.2$ staining is confined to segments. $\boldsymbol{E}-\boldsymbol{J}$, Double labeling for $\mathrm{K}_{\mathrm{v}} 2.1$ or $\mathrm{K}_{\mathrm{v}} 2.2$ with the cone photoreceptor marker, calbindin (CalB). $\mathrm{K}_{\mathrm{v}} 2.1$ is present in rod and cone inner segment membranes $(\boldsymbol{E}-\boldsymbol{G})$, whereas $\mathrm{K}_{\mathrm{V}} 2.2$ is restricted to cone inner segments $(\boldsymbol{H}-\boldsymbol{J}) . \boldsymbol{K}-\boldsymbol{M}$, Double labeling for the $\mathrm{K}_{\mathrm{v}} 8.2$ and $\mathrm{K}_{\mathrm{v}} 2.1$ channel subunits. $\mathrm{K}_{\mathrm{v}} 8.2$ is present in both rod and cone inner segment membranes where it is colocalized with $K_{v}$ 2.1. While $K_{v} 2$.1 is largely confined to the plasma membrane, $K_{v} 8.2$ also shows some weak immunoreactivity in the intracellular compartment. $\boldsymbol{N}-\boldsymbol{P}$, Double labeling for $\mathrm{K}_{\mathrm{v}} 2.1$ and $\mathrm{K}_{\mathrm{v}} 2.2$ channel subunits. Note the colocalization of subunits in cone inner segments. All confocal images are single optical sections. Scale bars: $\boldsymbol{A}, 20 \mu \mathrm{m}$; (in $\boldsymbol{P}) \boldsymbol{B}-\boldsymbol{P}, 10 \mu \mathrm{m}$. OS, Outer segment. HFL, Henle's

$\mathrm{K}_{\mathrm{V}} 8.2$ channel expression is highly conserved between mouse, macaque, and human photoreceptors, whereas $\mathrm{K}_{\mathrm{V}} 2.2$ subunits appear to be expressed in primate and rabbit, but not rodent, cones.

\section{$K_{V} 8.2$ is colocalized with $K_{V} 2$ channels in human} photoreceptor inner segments

Photoreceptor morphology differs between central and peripheral human retina, and $\mathrm{K}_{\mathrm{V}} 8.2$ mutations disproportionately affect the foveal region; therefore, we compared channel localization between central and peripheral human retina. We first examined the foveal slope region $(0-0.22 \mu \mathrm{m}$ eccentricity; Fig. $2 A)$, where rod photoreceptors are absent. At this eccentricity, $\mathrm{K}_{\mathrm{V}} 2.1$, 


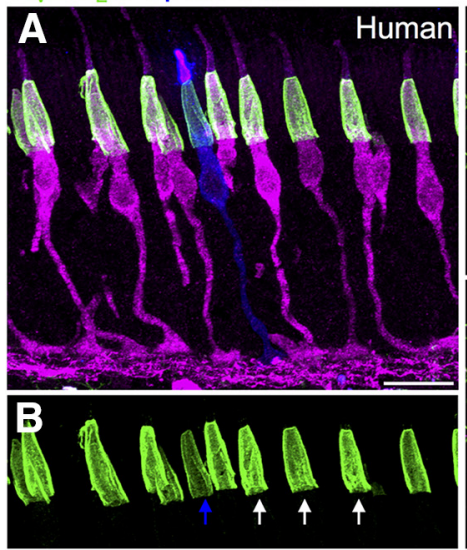

$\mathrm{K}_{\mathrm{V}} 2.2$ S-opsin L/M-opsin
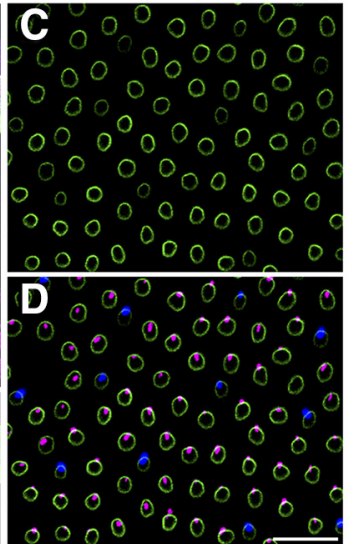

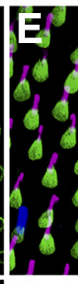

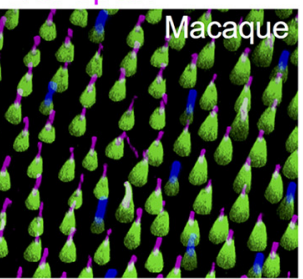

$F$

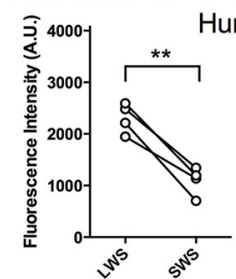

Figure 3. Primate $S$ cones express lower levels of $K_{v} 2.2$ than $L / M$ cones. $A$, Confocal projection of a vertical section of midperipheral human retina labeled for $\mathrm{S}$-opsin, calbindin $(\mathrm{CalB})$, and $\mathrm{K}_{\mathrm{V}} 2.2_{\mathrm{L}}$. $\boldsymbol{B}$, Same section as in $\boldsymbol{A}$ showing region containing photoreceptor inner segments (green channel only). The $3 \mathrm{~L} / \mathrm{M}$ cones (white arrows) and the one $S$ cone (blue arrow) are projections through complete inner segments. $\boldsymbol{C}-\boldsymbol{E}$, Confocal images of a macaque retinal whole-mount labeled for Kv2.2, S-opsin, and L/M-opsin. C, Focus is at the inner segments. D, Same $x-y$-z position in green projected onto $z$ planes from the photoreceptor outer segments to enable identification of cone spectral type. $\boldsymbol{E}$, Side projection of a different region of the same retina. The smaller and less intense $K_{v} 2.2$ staining is associated with the $S$ cone inner segments. $\boldsymbol{F}$, Relative fluorescence intensity of $K_{v} 2.2$ immunostaining in L/M cones (LWS) versus $S$ cones (SWS) in human retina. Lines connect measurements taken in the same retinas. ${ }^{* *} p=0.0029$. Scale bar, $20 \mu \mathrm{m}$.

$\mathrm{M}$ cones cannot be distinguished immunohistochemically, we grouped them together as L/M cones for analysis. Measurements in preparations from 4 different human retinas revealed that the intensity of $\mathrm{K}_{\mathrm{V}} 2.2$ fluorescence was $52 \pm$ $12 \%$ lower (mean $\pm \mathrm{SD}$ ) in the inner segments of $\mathrm{S}$ cones compared with $\mathrm{L} / \mathrm{M}$ cones $\left(t_{(3)}=8.9751, p=0.0029\right.$, onesample $t$ test, $114 \mathrm{~L} / \mathrm{M}$ and $111 \mathrm{~S}$ cones; Fig. $3 A, B, F)$. Qualitatively similar results were observed in whole mounts of macaque monkey retina that were stained for $\mathrm{K}_{\mathrm{V}} 2.2$, $\mathrm{L} / \mathrm{M}$-opsin, and S-opsin. In macaque, the intensity of $\mathrm{K}_{\mathrm{V}} 2.2$ staining was lower in a subset of smaller cone inner segment profiles (Fig. 3C). When the focal plane was shifted to the level of the outer segments, we found that these profiles were contiguous with cones expressing S-opsin (Fig. 3D,E). Together, these results indicate that $\mathrm{S}$ cones express lower levels of $\mathrm{K}_{\mathrm{V}} 2.2$ compared with $\mathrm{L} / \mathrm{M}$ cones in human and macaque retina.
$\mathrm{K}_{\mathrm{V}} 2.2_{\text {long }}$ (referred to herein as $\mathrm{K}_{\mathrm{V}} 2.2$ ), and $\mathrm{K}_{\mathrm{V}} 8.2$ immunoreactivity was concentrated in the membranes of cone inner segments (Fig. $2 B-D$ ) and cytosolic staining for $\mathrm{K}_{\mathrm{V}} 8.2$ was also present in this region (Fig. $2 D$ ). We then examined $K_{V}$ channel expression in peripheral retina where both rod and cone photoreceptors are present. Cones were distinguished from rods by their larger size and immunoreactivity for calbindin, which is present in human $\mathrm{L} / \mathrm{M}$ cones (Chiquet et al., 2002). $\mathrm{K}_{\mathrm{V}} 2.1$ immunoreactivity was apparent in both rod and cone inner segments, whereas $\mathrm{K}_{\mathrm{V}} 2.2_{\text {long }}$ was found only in cone inner segments (Fig. $2 E-J$ ). Like $\mathrm{K}_{\mathrm{V}} 2.1$, the $\mathrm{K}_{\mathrm{V}} 8.2$ subunit was present in both rod and cone inner segments, and these proteins were colocalized in the photoreceptor inner segment membranes (Fig. $2 K-M$ ). Double labeling for $K_{V} 2.1$ and $K_{V} 2.2$ showed that these subunits were colocalized in cone inner segment membranes (Fig. $2 \mathrm{~N}-\mathrm{P}$ ). It is important to note that $\mathrm{K}_{\mathrm{V}} 2$ subunit staining was diffusely distributed throughout the photoreceptor inner segment membrane; this is in stark contrast to most other central neurons where $\mathrm{K}_{\mathrm{V}} 2.1$ and $\mathrm{K}_{\mathrm{V}} 2.2$ subunits form giant $(\sim 1 \mu \mathrm{m})$ membrane clusters (see, e.g., Kihira et al., 2010; Bishop et al., 2015). Indeed, we found that both the $\mathrm{K}_{\mathrm{V}} 2.1$ (data not shown) and $\mathrm{K}_{\mathrm{V}} 2.2$ subunits (Fig. $1 B$ ) localized to giant clusters in ganglion cell membranes, indicating that the diffuse expression in photoreceptors cannot be accounted for by differences in sample preparation. Together, these results indicate that $\mathrm{K}_{\mathrm{V}} 2$ channel inventory differs between human rods and cones; cone inner segments express $\mathrm{K}_{\mathrm{V}} 2.1, \mathrm{~K}_{\mathrm{V}} 2.2_{\text {long }}$, and $\mathrm{K}_{\mathrm{V}} 8.2$ subunits, whereas rod inner segments contain only $\mathrm{K}_{\mathrm{V}} 2.1$ and $\mathrm{K}_{\mathrm{V}} 8.2$ subunits.

After viewing a large number of sections, we observed that the intensity of $\mathrm{K}_{\mathrm{V}} 2.2$ staining was systematically lower in a small subset of cones, and we hypothesized that these might represent short-wavelength-sensitive S cones ("blue" cones). To test this hypothesis, we immunolabeled retinal sections with $\mathrm{K}_{\mathrm{V}} 2.2, \mathrm{~S}$ cone opsin, and calbindin, a calcium-binding protein expressed in long (L) and medium (M) wavelength cones, but not $\mathrm{S}$ cones, in human retina (Chiquet et al., 2002) (Fig. $3 A, B$ ). Because L and

\section{$K_{V} 8.2$ and $K_{V} 2.1$ are expressed in mouse rod and cone inner segments}

To determine whether $\mathrm{K}_{\mathrm{V}} 8.2$ and $\mathrm{K}_{\mathrm{V}} 2.1$ were expressed in mouse cones as well as rods, we used PNA-lectin to distinguish between rod and cone inner segment membranes (Fig. 4). We found that $\mathrm{K}_{\mathrm{V}} 8.2$ (Fig. $4 A, B$ ) and $\mathrm{K}_{\mathrm{V}} 2.1$ (Fig. $4 C, D$ ) were present in the inner segment membranes of rods as well as PNA-labeled cones. $\mathrm{K}_{\mathrm{V}} 2.1$ and $\mathrm{K}_{\mathrm{V}} 8.2$ subunits were colocalized in mouse photoreceptor membranes (Fig. $4 E-G$ ). These results indicate that, as in human retina, $\mathrm{K}_{\mathrm{V}} 8.2$ and $\mathrm{K}_{\mathrm{V}} 2.1$ colocalize in mouse rod and cone photoreceptors.

\section{$\mathrm{K}_{\mathrm{V}}$ channels show highly compartmentalized expression in photoreceptors}

A striking feature of $\mathrm{K}_{\mathrm{V}}$ channel expression in human and mouse photoreceptors was the compartmentalized localization in the inner segment region of the photoreceptor membrane. To better define the proximal (inner) limit of $\mathrm{K}_{\mathrm{V}}$ channel localization, we immunolabeled mouse and human retina with $\mathrm{K}_{\mathrm{V}} 2.1$, and glutamine synthetase, a marker of Müller glia (Fig. 5A,B). The apical membranes of Müller cells are attached to each other and to the inner segments of photoreceptors by adherens junctions and tight-like junctions that together comprise the outer limiting membrane. In mouse retina, labeling for $\mathrm{K}_{\mathrm{V}} 2.1$ declined gradually in the proximal region of the inner segment before terminating at the level of the outer limiting membrane. In human retina, $\mathrm{K}_{\mathrm{V}}$ 2.1 labeling terminated abruptly at the level of the outer limiting membrane. These data indicate that $\mathrm{K}_{\mathrm{V}} 2$ and $\mathrm{K}_{\mathrm{V}} 8.2$ channels are selectively targeted to specific regions of the photoreceptor membrane.

Protein interactions between $K_{V} 8.2$ and $K_{V} 2$ channel subunits Our immunofluorescence data demonstrated colocalization of $\mathrm{K}_{\mathrm{V}} 2.1$ and $\mathrm{K}_{\mathrm{V}} 8.2$ in rods, and colocalization of $\mathrm{K}_{\mathrm{V}} 2.1, \mathrm{~K}_{\mathrm{V}} 2.2_{\text {long }}$, and $K_{V} 8.2$ in cones. To determine whether this colocalization 

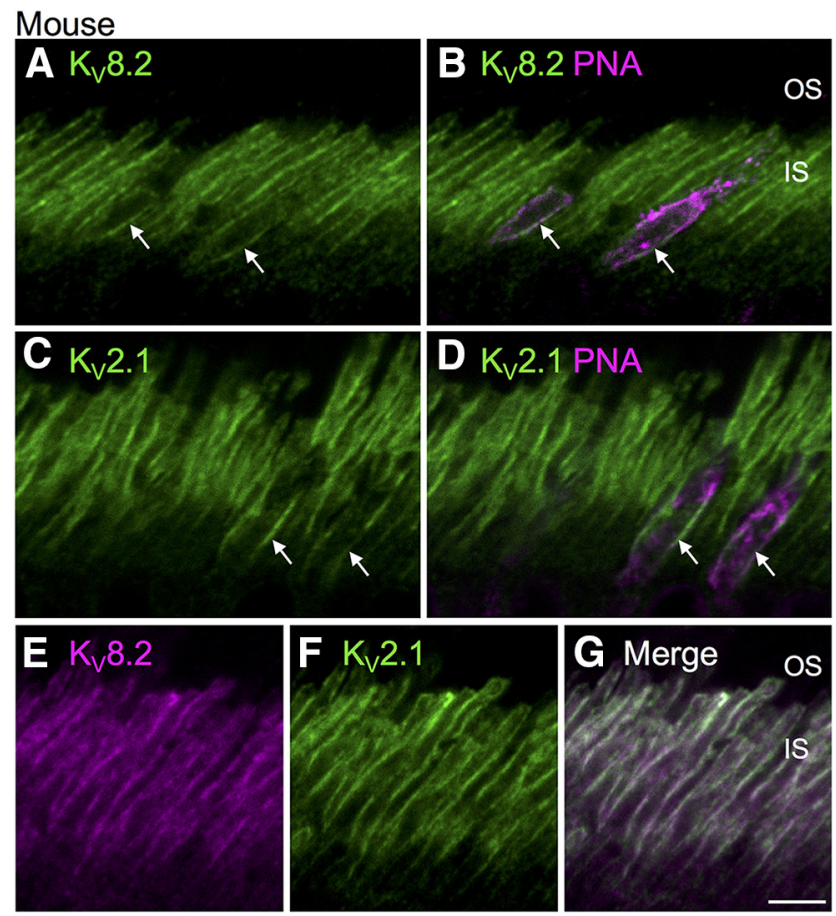

Figure 4. $\mathrm{K}_{\mathrm{V}} 2.1$ and $\mathrm{K}_{\mathrm{V}} 8.2$ are expressed in mouse rod and cone photoreceptors. Confocal optical sections of mouse outer retina labeled for $K_{v}$ subunits (green) and the cone photoreceptor marker, PNA (magenta). $\boldsymbol{A}, \boldsymbol{B}$, Double label for $\mathrm{K}_{\mathrm{v}} 8.2$ and PNA shows $\mathrm{K}_{\mathrm{v}} 8.2$ in PNA-positive cone inner segments (arrows) and in PNA-negative rod inner segments. $C, D$, Double label for $K_{v} 2.1$ and PNA shows $K_{v} 2.1$ in PNA-positive cone inner segments (arrows) and in PNA-negative rod inner segments. $\boldsymbol{E}-\boldsymbol{G}, K_{\mathrm{v}} 8.2$ (magenta) and $K_{\mathrm{V}} 2.1$ (green) subunits are colocalized (merged channel, $\mathbf{G}$ ) in the mouse inner segments. Scale bar, $5 \mu \mathrm{m}$.

\section{KV2.1GS}
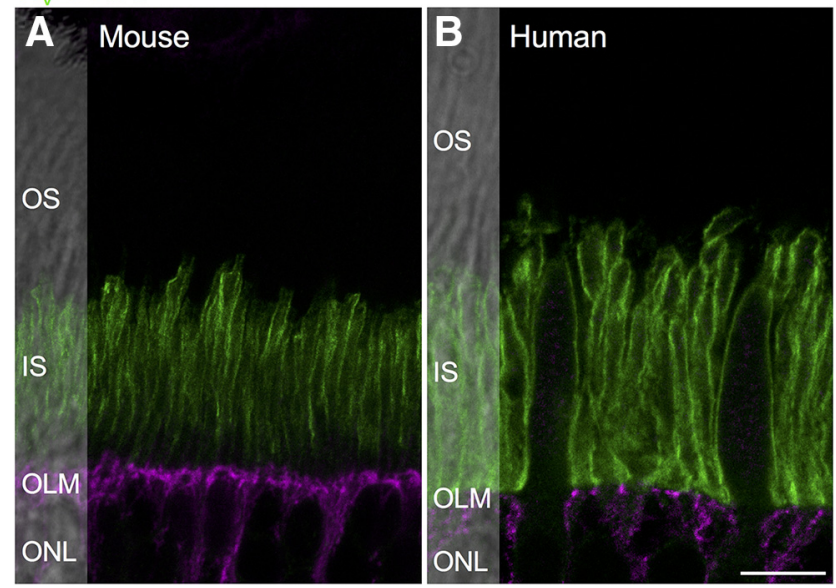

Figure 5. $\mathrm{K}_{\mathrm{v}} 2$ channels are concentrated in photoreceptor inner segments, distal to the outer limiting membrane. $\boldsymbol{A}, \boldsymbol{B}$, Confocal sections showing localization of Kv2.1 and glutamine synthetase (GS) in mouse ( $\boldsymbol{A})$ and human $(\boldsymbol{B})$ outer retina. In both species, Kv2.1 is concentrated in the inner segment, distal to the glutamine synthetase-immunolabeled outer limiting membrane. Scale bar, $10 \mu \mathrm{m}$.

reflected the presence of heteromeric $\mathrm{K}_{\mathrm{V}}$ channel complexes, as has been reported in the brain (Kihira et al., 2010), we performed co-immunoprecipitation experiments using macaque retinal lysates. Using an antibody for $\mathrm{K}_{\mathrm{V}} 2.1$ (K89) $(n=4$ experiments; Fig. $6 A$ ), we were able to co-immunoprecipitate $\mathrm{K}_{\mathrm{V}} 2.2$. To confirm this interaction, we performed the reciprocal experiment, using a $\mathrm{K}_{\mathrm{V}} 2 \cdot 2_{\text {long }}$ antibody (rabbit polyclonal, $n=5$ experiments) and were

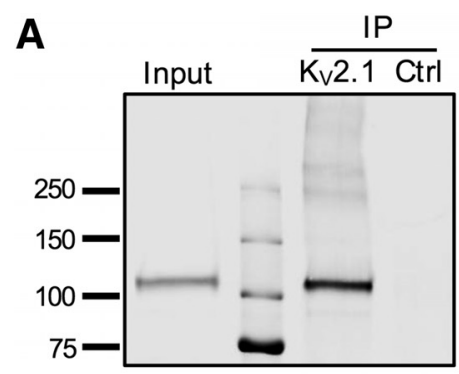

WB: ms anti-Kv2.1

B

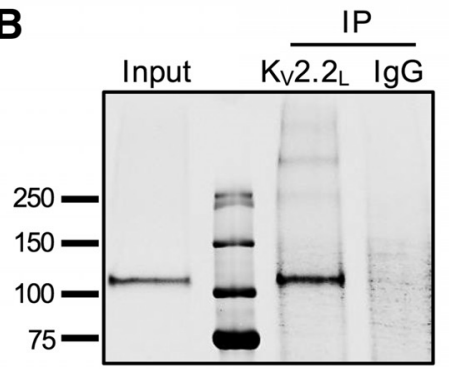

WB: ms anti-Kv2.1

C

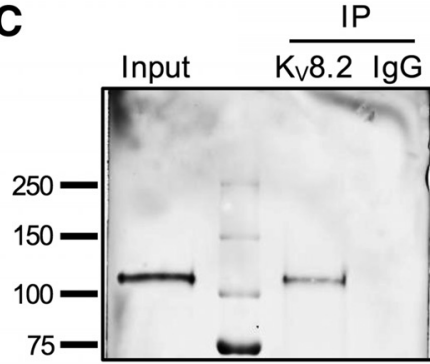

WB: ms anti-Kv2.1

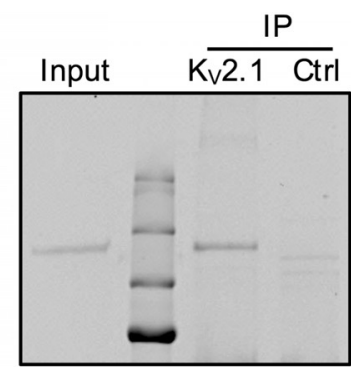

WB: ms anti-Kv2.2L

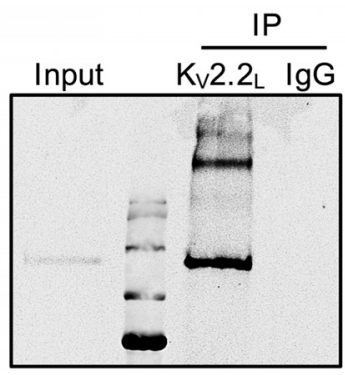

WB: $m s$ anti-Kv2.2L

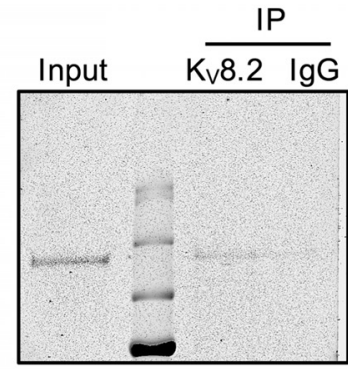

WB: $m s$ anti- $\mathrm{K}_{\mathrm{V}} 2.2 \mathrm{~L}$

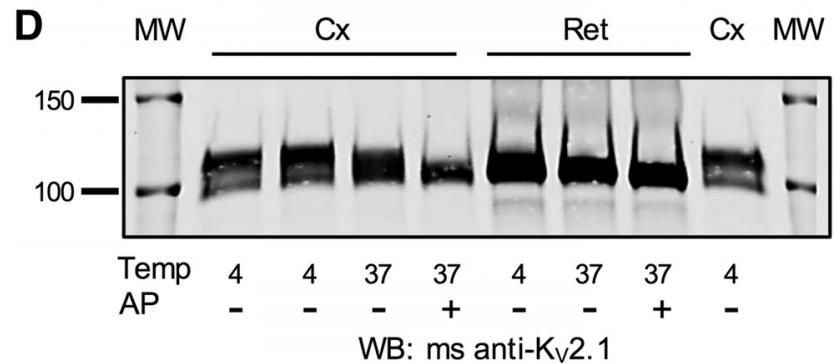

Figure 6. $K_{\mathrm{v}} 2$ and $K_{\mathrm{v}} 8.2$ subunits form heteromeric complexes. $\boldsymbol{A}-\boldsymbol{C}$, Macaque retinal lysates were subjected to immunoprecipitation with $\mathrm{K}_{\mathrm{V}} 2.1(\boldsymbol{A}), \mathrm{K}_{\mathrm{V}} 2.2_{\mathrm{L}}(\boldsymbol{B})$, or $\mathrm{K}_{\mathrm{v}} 8.2(\boldsymbol{C})$ antibodies. Control experiments were performed either with normal rabbit $\lg G(B, C, \lg G)$ or with an unrelated antibody ( $\boldsymbol{A}, \mathrm{Ctrl}$, mouse anti-VGAT). Precipitated proteins were detected by Western blotting (WB) with the antibodies indicated below each blot. $K_{v} 2.1$ antibodies immunoprecipitated $K_{v} 2.1$ and coimmunoprecipitated $K_{v} 2.2_{\text {long }}(A) \cdot K_{v} 2.2_{\text {long }}$ antibodies immunoprecipitated $\mathrm{K}_{\mathrm{v}} 2.2$ long and coimmunoprecipitated $\mathrm{K}_{\mathrm{v}} 2.1(\boldsymbol{B})$. In addition to the $\mathrm{K}_{\mathrm{v}} 2.1$ and $\mathrm{K}_{\mathrm{v}} 2.2_{\text {long }}$ monomers at $\sim 110$ and $\sim 130 \mathrm{kDa}$, additional heavier bands were detectable with both antibodies, suggesting detection of non-reduced heteromeric channels. $C, K_{v} 8.2$ antibodies coimmunoprecipitate both the $K_{v} 2.1$ and $K_{v} 2.2_{\text {long }}$ subunits. $D$, Example of mouse neocortical (CX) or retinal (Ret) protein lysates probed by Western blot for $K_{v} 2.1$. Samples were treated at temperatures (Temp) of $4^{\circ} \mathrm{C}$ or $37^{\circ} \mathrm{C}$ in the presence or absence of AP. Note the larger electrophoretic shift in cortical lysates compared with retinal lysates with AP treatment. Similar results were obtained in tissues from 4 animals. Molecular weight (MW) markers are shown on outside lanes.

able to co-immunoprecipitate $\mathrm{K}_{\mathrm{V}} 2.1$ (Fig. $6 B$ ). Consistent with previous studies, the $\mathrm{K}_{\mathrm{V}} 2.1$ and $\mathrm{K}_{\mathrm{V}} 2.2_{\text {long }}$ antibodies were highly specific for their target subunits (Bishop et al., 2015). The $\mathrm{K}_{\mathrm{V}} 2.1$ antibody recognized a major band at $\sim 110 \mathrm{kDa}$, whereas anti- 
A Cones
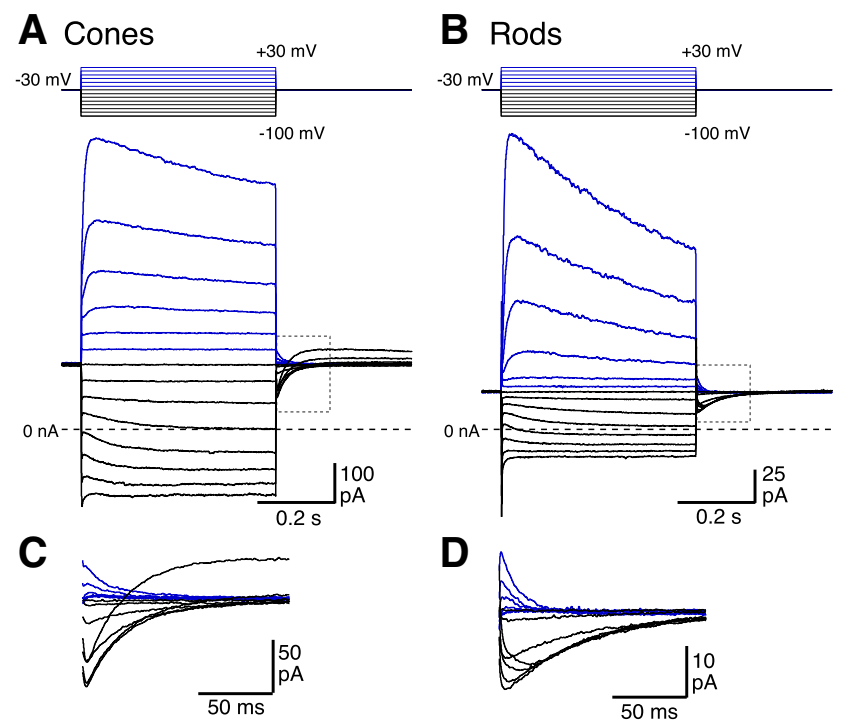

D

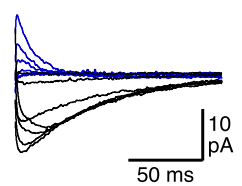

E

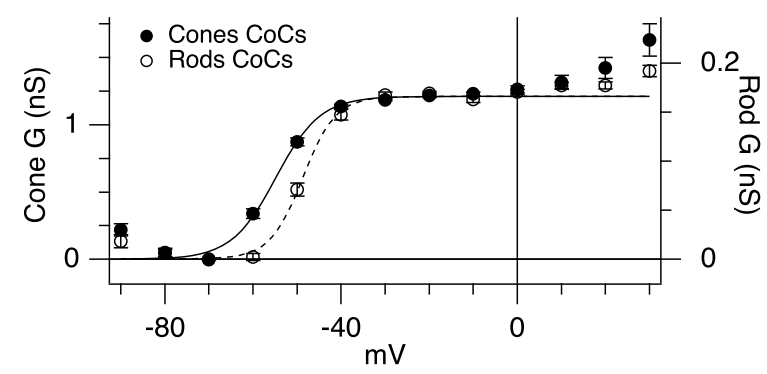

Figure 7. Rod and cone photoreceptors have distinct voltage-activated $K_{V}$ currents. $A-D$, Average voltage-activated currents in macaque cone $(\boldsymbol{A})$ and $\operatorname{rod}(\boldsymbol{B})$ photoreceptors in response to the voltage step protocol shown above the traces. Voltage steps were $0.5 \mathrm{~s}$ long. Black and blue traces represent hyperpolarizing and depolarizing voltage steps, respectively. Dashed line indicates the zero current level. Gray dotted bounding boxes represent the tail currents, which are shown on an expanded scale in $\boldsymbol{C}$ and $\boldsymbol{D}$. The tail currents evoked from steps to -90 and $-100 \mathrm{mV}$ show an outward current that may be due to relief of inactivation of an A-type $K_{V}$ current. Current traces are averages of 15 cones and 12 rods. $\boldsymbol{E}$, Cone (solid circles, $n=19$ ) and rod (open circles, $n=12$ ) conductance (mean \pm SEM) calculated from tail currents and shown as a function of voltage. Solid and dashed lines indicate fits to a simple Boltzmann function.

bodies for $\mathrm{K}_{\mathrm{V}} 2.2_{\text {long }}$ detected a major band at $\sim 140 \mathrm{kDa}$ (Fig. $6 A, B)$. In addition to the major bands at the predicted weights of the $\mathrm{K}_{\mathrm{V}}$ subunit monomers, the $\mathrm{K}_{\mathrm{V}} 2.1$ and $\mathrm{K}_{\mathrm{V}} 2.2_{\text {long }}$ antibodies detected heavier bands at $\sim 250 \mathrm{kDa}$ and $>250 \mathrm{kDa}$ that may represent nonreduced heteromeric assemblies containing $\mathrm{K}_{\mathrm{V}} 2.1$ and $\mathrm{K}_{\mathrm{V}} 2.2_{\text {long. }}$.

$\mathrm{K}_{\mathrm{V}} 2.1$ and $\mathrm{K}_{\mathrm{V}} 8.2$ are reported to interact in expression systems (Ottschytsch et al., 2002; Czirják et al., 2007; Smith et al., 2012); however, there is no evidence for native interactions. Moreover, to our knowledge, interactions between $\mathrm{K}_{\mathrm{V}} 8.2$ and $\mathrm{K}_{\mathrm{V}} 2.2$ have not been shown. Using the rabbit anti- $\mathrm{K}_{\mathrm{V}} 8.2$ antibody, we coimmunoprecipitated both $\mathrm{K}_{\mathrm{V}} 2.1\left(n=2\right.$ experiments) and $\mathrm{K}_{\mathrm{V}} 2.2$ ( $n=2$ experiments) (Figure $6 C$ ). Because $\mathrm{K}_{\mathrm{V}} 8.2$ was expressed primarily in human and macaque photoreceptors (Fig. 1C), we conclude that the observed protein-protein interactions likely arise from photoreceptors rather than inner retinal neurons. Although the rabbit anti- $\mathrm{K}_{\mathrm{V}} 8.2$ antibody recognized the target protein for immunohistochemistry and immunoprecipitation, it did not recognize specific bands on Western blots, suggesting that optimal antibody binding depends on the tertiary structure of the epitope. We confirmed specificity of the subunit interactions by showing that $\mathrm{K}_{\mathrm{V}} 2$ proteins were not immunoprecipitated with an unrelated monoclonal antibody (Fig. 6A) or with nonimmune rabbit IgG antibody (Fig. 6B, C). Together, these data demonstrate that $K_{V} 8.2$ interacts with both $K_{V} 2.1$ and with $K_{V} 2.2$ in primate retina.

\section{$\mathrm{K}_{\mathrm{V}} 2.1$ is less phosphorylated in retina compared with cortex}

The $\mathrm{K}_{\mathrm{V}} 2.1$ protein has upward of $\sim 30$ phosphorylation sites, and its membrane localization pattern and gating can be dynamically modified through phosphoregulation (Misonou et al., 2005). Changes in localization are associated with changes in phosphorylation state. For example, in cortical neurons, $\mathrm{K}_{\mathrm{V}} 2.1$ normally aggregates into large membrane clusters, but these clusters disperse when $\mathrm{K}_{\mathrm{V}} 2.1$ is dephosphorylated (Misonou et al., 2004; Bishop et al., 2015). Dephosphorylation also changes the biophysical properties of $\mathrm{K}_{\mathrm{V}} 2.1$ channels, shifting the voltage dependence of activation to substantially more hyperpolarized potentials (Misonou et al., 2004; Park et al., 2006; O'Connell et al., 2010). Given the diffuse pattern of localization of $\mathrm{K}_{\mathrm{V}} 2.1$ in photoreceptor inner segment membranes (Figs. 1, 2), we hypothesized that retina-derived $\mathrm{K}_{\mathrm{V}} 2.1$ would be less phosphorylated than $\mathrm{K}_{\mathrm{V}} 2.1$ from cortical lysates. In support of this idea, the weight of $\mathrm{K}_{\mathrm{V}} 2.1$ in macaque retinal samples was $\sim 110 \mathrm{kDa}$ (Fig. 6), whereas in most brain regions, the molecular weight is closer to $125 \mathrm{kDa}$ and can be shifted to 95-105 kDa after phosphatase treatment (Murakoshi et al., 1997; Cerda and Trimmer, 2011). To test whether $\mathrm{K}_{\mathrm{V}} 2.1$ protein is less phosphorylated in retina compared with other brain regions, we immunoblotted crude lysates of mouse cortex and retina that were treated with and without $\mathrm{AP}$ (Fig. 6D). In retinal lysates, AP treatment resulted in a relative electrophoretic mobility shift of $\mathrm{K}_{\mathrm{V}} 2.1$ of $\sim 3 \pm 1.00 \mathrm{kDa}(n=4$ mice), whereas a significantly larger shift was evident in cortical lysates $\sim 10 \pm 0.98$ $\mathrm{kDa}\left(t_{(3)}=3.18, p=0.0008\right.$, paired $t$ test, $n=4$ mice; Fig. $\left.6 D\right)$. Because the overall level of $\mathrm{K}_{\mathrm{V}} 2.1$ expression is substantially higher in photoreceptors than in the inner retina (Fig. 1D), we reasoned that the major $\mathrm{K}_{\mathrm{V}} 2.1$ band detected in our protein experiments likely originated from photoreceptors. Our results support the notion that $\mathrm{K}_{\mathrm{V}} 2.1$ protein is less phosphorylated in photoreceptors compared with in other central neurons, a finding that may account for the diffuse localization of Kv2.1 protein in photoreceptors. The more hyperpolarized activation expected for dephosphorylated $\mathrm{K}_{\mathrm{V}} 2.1$ channels may be important for shifting the activation of these channels into the photoreceptor voltage operating range.

\section{Functional evidence for $\mathrm{K}_{\mathrm{V}} 2$ containing channels in primate photoreceptors}

Our immunohistochemical data showed that $\mathrm{K}_{\mathrm{V}} 8.2$-containing channels are expressed with $\mathrm{K}_{\mathrm{V}} 2.1$ in rods and with $\mathrm{K}_{\mathrm{V}} 2.1$ and $\mathrm{K}_{\mathrm{V}} 2.2$ in cones. What is the functional impact of these compositional differences? Do $\mathrm{K}_{\mathrm{V}} 8.2-\mathrm{K}_{\mathrm{V}} 2$ heteromers mediate the low-voltage-activated delayed-rectifier current $\left(\mathrm{I}_{\mathrm{Kx}}\right)$ described previously in salamander rods (Beech and Barnes, 1989)? To address these questions, we made voltage-clamp recordings from rods and cones in macaque monkey retina (Fig. 7). To study the voltage dependence of rod and cone $\mathrm{K}_{\mathrm{V}}$ currents, and to compare currents with previous studies (Beech and Barnes, 1989), we voltageclamped cells at a holding potential of $-30 \mathrm{mV}$ (a potential where $\mathrm{I}_{\mathrm{Kx}}$ was expected to be maximally activated) and made voltage steps between $30 \mathrm{mV}$ and $-90 \mathrm{mV}$ in $10 \mathrm{mV}$ increments (Fig. $7 A, B)$. To improve voltage-clamp and to better isolate potassium currents, we added $4 \mathrm{~mm} \mathrm{CsCl}$ to the external solution to block hyperpolarization-activated currents $\left(\mathrm{I}_{\mathrm{h}}\right)$ and replaced $\mathrm{Ca}^{2+}$ with $\mathrm{Co}^{2+}$ ions to block voltage-gated calcium, calcium- 
Table 2. Summary of gating properties of low-voltage activated $\mathrm{K}_{\mathrm{V}}$ current in rods and cones ${ }^{a}$

\begin{tabular}{|c|c|c|c|}
\hline & Cones & Rods & Statistics \\
\hline Outward current at $-30 \mathrm{mV}(\mathrm{pA})$ & $149 \pm 57$ (19 cells) & $29 \pm 4$ (12 cells) & $t_{(18)}=9.09, p<0.0001^{b}$ \\
\hline Cell capacitance (pF) & $\begin{array}{l}13.37 \pm 2.98 \text { (19 cells) } \\
\text { range } 9.2-22.3\end{array}$ & $\begin{array}{l}3.78 \pm 0.68 \text { (12 cells) } \\
\text { range } 3.18-5.26\end{array}$ & $t_{(21)}=13.48, p<0.0001^{b}$ \\
\hline Current density $(\mathrm{pA} / \mathrm{pF})$ & $11.22 \pm 3.66$ (19 cells) & $7.75 \pm 1.72$ (12 cells) & $t_{(27)}=3.56, p=0.0007^{b}$ \\
\hline Current density-maximum $C_{m}(p A / p F)$ & $6.66 \pm 2.57$ (19 cells) & $5.44 \pm 0.82$ (12 cells) & $t_{(23)}=1.92, p=0.07^{b}$ \\
\hline Maximal conductance & $1.23 \pm 0.22 \mathrm{nS}(19$ cells $)$ & $179 \pm 55$ pS (12 cells) & $t_{(21)}=20.45, p<0.0001$ \\
\hline$V_{1 / 2}$ activation $(\mathrm{mV})$ & $-55 \pm 4$ (19 cells) & $-48 \pm 3$ (12 cells) & $t_{(29)}=5.32, p<0.0001^{c}$ \\
\hline$k(\mathrm{mV})$ & $4.75 \pm 1.7$ (19 cells) & $3.79 \pm 1.8$ ( 12 cells $)$ & $t_{(29)}=1.50, p=0.14^{c}$ \\
\hline$\tau_{\text {deact }}(\mathrm{ms})$ at $-60 \mathrm{mV}$ & $116 \pm 43$ (13 cells) & $109 \pm 35$ (12 cells) & $t_{(23)}=0.46, p=0.65^{c}$ \\
\hline$\tau_{\text {act }}(\mathrm{ms})$ at $-30 \mathrm{mV}$ (pre-pulse $-80 \mathrm{mV}$ ) & $33 \pm 14$ (12 cells) & $74 \pm 26$ (11 cells) & $t_{(15)}=4.60, p=0.0035^{b}$ \\
\hline
\end{tabular}

${ }^{a}$ Values are mean \pm SD.

${ }^{b}$ Welch's $t$ test (unequal variance).

' $t$ test (equal variance)

activated chloride and calcium-activated potassium channels (Barnes and Deschênes, 1992; Yagi and Macleish, 1994; Xu and Slaughter, 2005). This CoCs-Ames' solution served as the "control" solution for this and all subsequent experiments. At the holding potential of $-30 \mathrm{mV}$, both rods and cones exhibited a noninactivating outward current, which was $\sim 5$ times larger in cones (Fig. 7 $A, B$, note difference in vertical calibration bars; Table 2). When taking the average cell capacitance into account $(\sim 3.5 \times$ higher in cones, Table 2$)$, the calculated current densities $(\mathrm{pA} / \mathrm{pF})$ were significantly different (Table 2$)$. However, during our recordings, we observed that some cones were missing part or all of their outer segments, which likely contributed to the higher variance in the measured cone capacitance. Intact photoreceptors will have the highest capacitance values in the sample. Therefore, to obtain an estimate of the current density in intact photoreceptors, we calculated current density based on the maximal $\mathrm{C}_{\mathrm{m}}$ values obtained for each dataset (cone maximum capacitance $22.3 \mathrm{pF}$, rod maximum capacitance $5.26 \mathrm{pF}$ ). Using these maximal $\mathrm{C}_{\mathrm{m}}$ values, the current densities in rods and cones were comparable (Table 2). These results indicate that both primate rods and cones exhibit a noninactivating outward current when held near the dark resting membrane potential.

A characteristic feature of the previously described $\mathrm{I}_{\mathrm{Kx}}$ current is its slow shutoff in response to hyperpolarizing voltage steps and its slow reactivation upon repolarization (Beech and Barnes, 1989). Similarly, we found that, in both rods and cones, hyperpolarizing steps from $-30 \mathrm{mV}$ resulted in the development of a time-dependent inward current that reversed at the calculated $\mathrm{K}^{+}$reversal potential (Fig. $7 A, B$, black traces) consistent with the slow closure of $K_{V}$ channels (Beech and Barnes, 1989). Upon repolarization to $-30 \mathrm{mV}$, a slow tail current was activated, returning the cell to its pre-step current level (Fig. $7 A-D$ ). We measured the voltage dependence of activation from the amplitude of these tail currents and converted to conductance, based on a calculated $\mathrm{K}^{+}$reversal potential of $-98 \mathrm{mV}$. In cones, Boltzmann fits showed an average voltage of half-maximal activation $\left(\mathrm{V}_{1 / 2}\right)$ of $-55 \mathrm{mV}$, maximal conductance of $1.23 \mathrm{nS}$ and a slope factor of $4.8 \mathrm{mV}$ (Fig. $7 E$; Table 2 ). In rods, $\mathrm{V}_{1 / 2}$ for activation was significantly more depolarized $(-48 \mathrm{mV})$ and the maximal conductance was lower, whereas the slope factor was comparable with cones (Fig. 7E; Table 2). To measure the activation kinetics of the $\mathrm{I}_{\mathrm{Kx}}$-like currents, we fit a single exponential to the tail currents evoked upon stepping from $-80 \mathrm{mV}$ to $-30 \mathrm{mV}$. The mean time constant for activation of the tail currents was approximately twofold slower in rods compared with cones (Table 2). On the other hand, the deactivation time constants, fitted to cur- rents activated upon stepping from $-30 \mathrm{mV}$ to $-60 \mathrm{mV}$, were similar in rods and cones (Table 2). Together, these data indicate that primate rods and cones possess a low-voltage-activated current with properties similar to the $\mathrm{I}_{\mathrm{Kx}}$ current described previously in amphibian retina. The activation range and kinetics of these currents differ in rods compared with cones.

In both rods and cones, the low-voltage-activated potassium conductance appeared to be maximally activated at $\sim-30 \mathrm{mV}$ (Fig. $7 E$ ). However, for depolarizing voltage steps positive to $\sim 0$ $\mathrm{mV}$, an additional, high-voltage-activated outward current was observed (Fig. $7 A, B$ ). This high-voltage-activated current gradually declined in amplitude during the voltage-step, consistent with slow channel inactivation. We found that, during the $500 \mathrm{~ms}$ voltage steps from $-30 \mathrm{mV}$ to $30 \mathrm{mV}$, rods showed a greater degree of inactivation than cones when measured at two fixed time points (\% inactivation, mean \pm SD: cones $13 \pm 5.1 \%, 19$ cells, 7 animals; rods $34 \pm 11 \%, 12$ cells, 4 animals, $t_{(15)}=5.97$, $p=2.55 \mathrm{e}^{-05}$, Welch's $t$ test). Together, these data indicate that photoreceptors express a high-voltage-activated potassium current in addition to a low-voltage-activated potassium current. The high-voltage-activated potassium current has different gating properties in rods versus cones. In the next section, we examine the pharmacology of these distinct current components.

In salamander rods, millimolar concentrations of external $\mathrm{Ba}^{2+}$ produce a rightward shift in the voltage dependence of $\mathrm{I}_{\mathrm{Kx}}$ activation, and a reduction in the slope of the activation curve (Beech and Barnes, 1989). Similar effects on the voltage dependence of activation have been reported with application of barium to oocytes expressing $\mathrm{K}_{\mathrm{V}} 2.1 / \mathrm{K}_{\mathrm{V}} 8.2$ (Czirják et al., 2007). In monkey cones, bath application of $\mathrm{Ba}^{2+}(5 \mathrm{~mm})$ shifted the voltage dependence of potassium channel activation to significantly more depolarized potentials $\left(\mathrm{V}_{1 / 2}, \mathrm{Ctrl}-54.7 \pm 3.8 \mathrm{mV}, \mathrm{Ba}^{2+}\right.$ $-30.5 \pm 11.3 \mathrm{mV}, t_{(3)}=4.40, p=0.022$, paired $t$ test, $n=4$ cones; Fig. $8 A-E)$. The slope factor of the Boltzmann fits was also significantly increased $\left(k, \operatorname{Ctrl} 4.8 \pm 0.3 \mathrm{mV}, \mathrm{Ba}^{2+} 14.3 \pm 3.7 \mathrm{mV}\right.$, $t_{(3)}=4.94, p=0.016$, paired $t$ test, $n=4$ cones). In addition, $\mathrm{Ba}^{2+}$ reduced the outward holding current by $\sim 50 \%$, consistent with the rightward shift in the $\mathrm{V}_{1 / 2}$ potential resulting in a partial shutoff of the tonic $\mathrm{I}_{\mathrm{Kx}}$ current (Ctrl, $134 \pm 44 \mathrm{pA}, \mathrm{Ba}^{2+} 71 \pm 24$ $\mathrm{pA}, t_{(6)}=5.46, p=0.0016$, paired $t$ test, $n=7$ cones; Fig. $8 A, B, F)$. These effects are similar to the effect of $\mathrm{Ba}^{2+}$ on heterologously expressed $\mathrm{K}_{\mathrm{V}} 2.1 / \mathrm{K}_{\mathrm{V}} 8.2$ channels (Czirják et al., 2007). However, $\mathrm{Ba}^{2+}$ application produced a larger overlap in the activation ranges of the low- and high-threshold $\mathrm{K}_{\mathrm{V}}$ currents, which made it difficult to accurately resolve the gating parameters. Overall, the effects of $\mathrm{Ba}^{2+}$ suggest that the low-voltage-activated $\mathrm{K}_{\mathrm{V}}$ may arise from $\mathrm{K}_{\mathrm{V}} 2.1 / \mathrm{K}_{\mathrm{V}} 8.2$ heteromeric channels. 
A

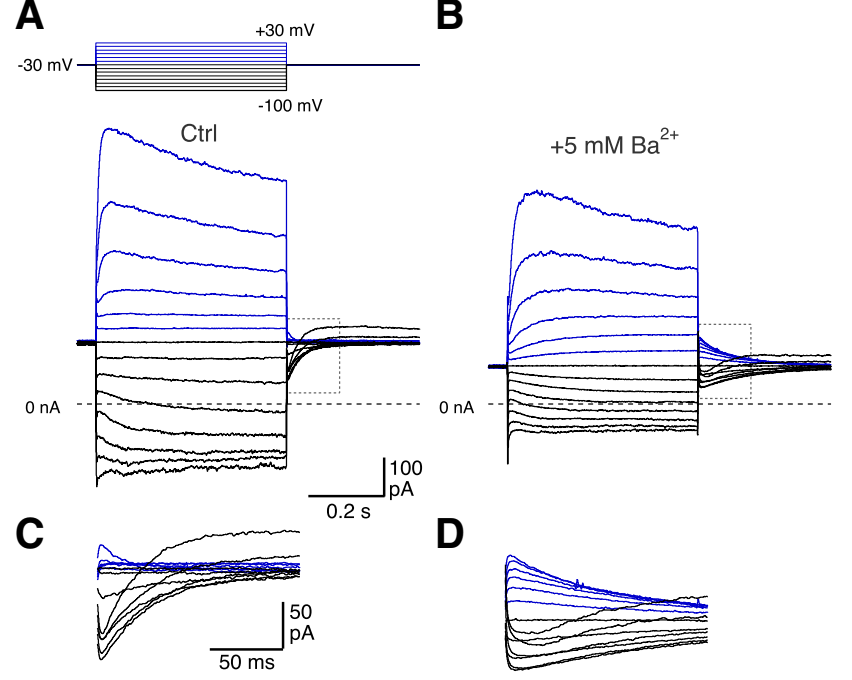

E
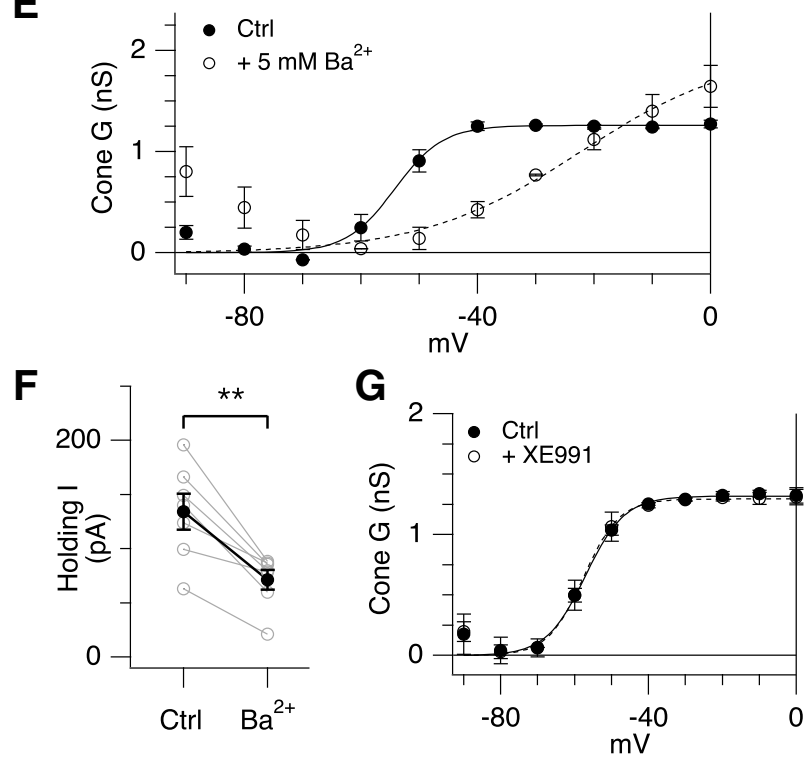

Figure 8. Barium shifts the activation of the low-voltage-activated $K_{V}$ currents in cones. $\boldsymbol{A}-\boldsymbol{D}$, Average voltage-activated currents from macaque cones that were recorded before $(\boldsymbol{A})$ and after $(\boldsymbol{B})$ application of $5 \mathrm{~mm} \mathrm{Ba}{ }^{2+}$. Control traces represent a subset of cells shown in Fig. $7 \boldsymbol{A}$. Voltage step protocol is shown above traces. Tail currents are highlighted by the gray bounding box and shown on an expanded scale in $\boldsymbol{C}, \boldsymbol{D}$. The tail currents evoked from steps to -90 and $-100 \mathrm{mV}$ show an outward current that may be due to relief of inactivation of an A-type $K_{V}$ current. $\boldsymbol{E}$, Cone conductance before (solid circles, $n=5$ ) and after application of $5 \mathrm{~mm} \mathrm{Ba}^{2+}$ (open circles, $n=5$ ) (mean \pm SEM) shown as a function of voltage. Solid and dashed lines indicate Boltzmann fits. $\boldsymbol{F}$, Holding current (at $-30 \mathrm{mV}$ ) before and after application of $5 \mathrm{~mm}$ $\mathrm{Ba}^{2+}$. Solid symbols represent mean \pm SEM. Gray symbols represent individual cells. ${ }^{* *} t_{(6)}=$ $5.46, p=0.0016$, paired $t$ test. $\mathbf{G}$, Cone conductance before (solid circles) and after application of $25 \mu \mathrm{M}$ XE991 (open circles) (mean \pm SEM, $n=3$ ) shown as a function of voltage.

The low-voltage threshold for activation of $\mathrm{I}_{\mathrm{Kx}}$ is similar to that seen for $\mathrm{K}_{\mathrm{V}} 7$-mediated currents ( $\mathrm{M}$ currents), and previous immunohistochemical studies have reported Kv7 channels in primate photoreceptor inner segments (Zhang et al., 2011). However, Beech and Barnes (1989) argued against $\mathrm{K}_{\mathrm{V}} 7$ channels generating $\mathrm{I}_{\mathrm{Kx}}$ because hallmark features of $M$ currents, such as sensitivity to acetylcholine and blockade by $\mathrm{Ba}^{2+}$, were lacking. Similarly, we found that external Ba ions did not block the lowvoltage-activated current in primate cones. To obtain further evidence to rule out the involvement of $\mathrm{K}_{\mathrm{V}} 7$ channels, we tested the effect of the selective $\mathrm{K}_{\mathrm{V}} 7$ channel blocker, XE991, on cones.
Application of XE991 had no significant effect on the amplitude of the tonic outward current at $-30 \mathrm{mV}$ (control $234 \pm 131 \mathrm{pA}$, XE991 $186 \pm 85 \mathrm{pA}, t_{(2)}=1.33, p=0.31, n=3$ cells, paired $t$ test) or on the voltage dependence of activation of the low-voltageactivated $K_{V}$ current $\left(V_{1 / 2}\right.$ activation, control $-57.2 \pm 3.6 \mathrm{mV}$ vs XE991 $-57.4 \pm 4.9 \mathrm{mV}, t_{(2)}=0.31, p=0.78, n=3$ cells; $k$, control $5.4 \pm 1.0 \mathrm{mV}$ vs XE991 $4.9 \pm 1.2 \mathrm{mV}, t_{(2)}=0.63, p=$ $0.59, n=3$ cells, paired $t$ tests; Figure $8 G$ ). Together, these data argue against the involvement of $\mathrm{K}_{\mathrm{V}} 7$ channels in generating the low-voltage-activated $\mathrm{K}_{\mathrm{V}}$ current in photoreceptors.

We next asked whether we could pharmacologically distinguish the low- and high-voltage-activated $\mathrm{K}_{\mathrm{V}}$ currents in cones. In these experiments, we measured the net voltage-gated potassium current activated during depolarizing steps from a holding potential of $-70 \mathrm{mV}$. First, we tested the sensitivity of the $\mathrm{K}_{\mathrm{V}}$ current to bath application of the peptide toxin, GxTX-1E (100 $\mathrm{nM}$ ), which has been shown to block both native and heterologously expressed homomeric $\mathrm{K}_{\mathrm{V}} 2.1$ and $\mathrm{K}_{\mathrm{V}} 2.2$ channels (Herrington et al., 2006; Liu and Bean, 2014). We found that GxTX-1E suppressed the voltage-gated current activated at potentials positive to $-20 \mathrm{mV}$, whereas the current activated at more negative potentials was unaffected $\left(35 \pm 13 \%\right.$ suppressed at $10 \mathrm{mV}, t_{(3)}=$ 4.43, $p=0.021 ; 10 \pm 30 \%$ suppressed at $-30 \mathrm{mV}, t_{(3)}=1.09, p=$ 0.35 , paired $t$ tests, $n=4$ cells; Figure $9 A, B)$. Boltzmann fits to the GxTX-1E-sensitive conductance showed a $V_{1 / 2}$ for activation of $-3.6 \pm 7.0 \mathrm{mV}$ and a slope factor of $8.0 \pm 0.4 \mathrm{mV}$ ( $n=3$ cones), consistent with the expected activation of homomeric $\mathrm{K}_{\mathrm{V}} 2$ containing channels in other central neurons $\left(\mathrm{V}_{1 / 2} \sim-10\right.$ to 10 $\mathrm{mV}$ ) (Bishop et al., 2015; Kimm et al., 2015). We also tested the effect of focal application of GxTX-1E onto rod and cone inner segments during step depolarizations from $-30 \mathrm{mV}$ to $40 \mathrm{mV}$ (Fig. 9C). Under these conditions, GxTX-1E suppressed the gated current by an average of $60 \pm 16 \%$ in 6 rods and $64 \pm 45 \%$ in 2 cones. The toxin did not affect the standing outward current at the $-30 \mathrm{mV}$ holding potential (Fig. 9C), consistent with a lack of effect on $\mathrm{I}_{\mathrm{Kx}}$. Together, these data support the presence of two functionally distinct populations of $\mathrm{K}_{\mathrm{V}}$ channels in primate cones: (1) a GxTX-1E-sensitive, high-voltage-activated $\mathrm{K}_{\mathrm{V}}$ current that likely arises from homomeric $\mathrm{K}_{\mathrm{V}} 2$ channels; and (2) a GxTX-1E-insensitive, low-voltage-activated current that is similar to IKx and may arise from $\mathrm{K}_{\mathrm{V}} 2 / \mathrm{K}_{\mathrm{V}} 8.2$ heteromers. Previous studies indicate that modifier subunits can alter the sensitivity of $\mathrm{K}_{\mathrm{V}} 2$ channels to peptide toxins, such as stromatoxin and GxTX-1E as well as to small-molecule blockers, such as 4-AP (for review, see Bocksteins, 2016). For example, in expression systems, the modifier subunit $K_{V} 6.3$ renders $K_{V} 2.1$ channels less sensitive to GxTX-1E (Moreno-Domínguez et al., 2009), and it is possible that $\mathrm{K}_{\mathrm{V}} 8.2$ may alter $\mathrm{K}_{\mathrm{V}} 2.1$ pharmacology in a similar way. We cannot, however, rule out the possibility that another type of $\mathrm{K}_{\mathrm{V}}$ channel mediates the low-voltage-activated current.

Additional evidence for the presence of functionally distinct populations of $\mathrm{K}_{\mathrm{V}}$ channels in cones is provided by the effects of the clinically used antidepressant citalopram. Citalopram, a selective serotonin reuptake inhibitor, suppresses homomeric $\mathrm{K}_{\mathrm{V}} 2.1$ - and $\mathrm{K}_{\mathrm{V}}$ 2.2-mediated currents in expression systems (Zhan et al., 2012). Bath application of citalopram caused a dose-dependent suppression of the high-voltage-activated $\mathrm{K}_{\mathrm{V}}$ currents; at a test potential of $40 \mathrm{mV}$, the $\mathrm{IC}_{50}$ for citalopram blockade was $6.6 \mu \mathrm{M}$ (Fig. 10A,B). Conversely, the low-voltage-activated $\mathrm{K}_{\mathrm{V}}$ currents (test potential $-40 \mathrm{mV}$ ) were relatively resistant to citalopram (Fig. 10C). In summary, analysis of the voltage-dependent currents and their sensitivity to $\mathrm{Ba}^{2+}, \mathrm{GxTX}-1 \mathrm{E}$, and citalopram 
A
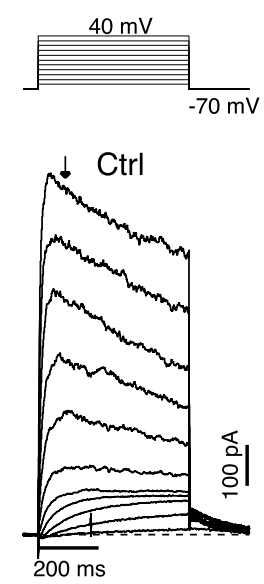

B

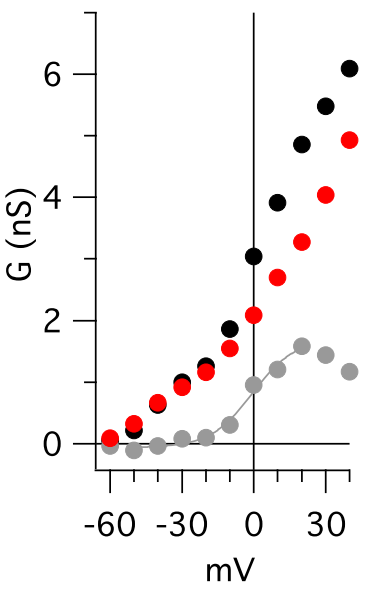

C
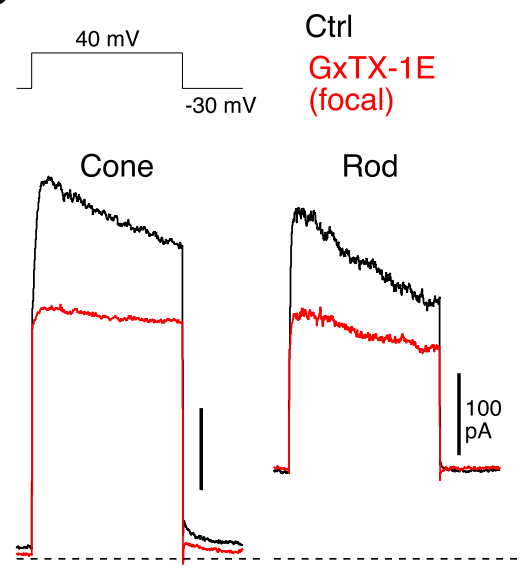

Figure 9. GxTX-1E blocks a high-voltage-activated $\mathrm{K}_{\mathrm{V}}$ current in rods and cones. $\boldsymbol{A}$, Voltage-activated currents in a macaque cone recorded before $\left(\boldsymbol{A}\right.$, black traces, $C_{0}(\mathrm{C}$ Ames') and after wash-in of $100 \mathrm{~nm}$ GxTX-1E (A, red traces). Cells were held at $-70 \mathrm{mV}$ and stepped to $40 \mathrm{mV}$ in $10 \mathrm{mV}$ increments. $\boldsymbol{B}$, Conductance shown as a function of voltage for the cell shown in $\boldsymbol{A}$. $\boldsymbol{A}$, Arrows indicate the time point at which conductance measurements were taken. Gray symbols represent the GxTX-1E-sensitive current (CoCs-GxTx-1E). Gray line indicates the Boltzmann fit to an individual cell showing a $\mathrm{V}_{1 / 2}$ of $0.6 \mathrm{mV}, k=8 \mathrm{mV}$, maximum conductance of $1.76 \mathrm{nS}$. C, Voltage-activated $\mathrm{K}_{\mathrm{V}}$ current shown before (Ctrl) and after focal application of GxTX-1E in a cone and rod. Note the suppression of the gated outward current in the presence of GxTx-1E.

provide strong evidence for functional $\mathrm{K}_{\mathrm{V}} 2$-containing channels in primate cones.

\section{Discussion}

Mutations in $\mathrm{K}_{V} 8.2$ lead to retinal dysfunction in humans, but the basis of these deficits is not well understood. Our data indicate that $\mathrm{K}_{V} 8.2$ is expressed with $\mathrm{K}_{V} 2.1$ in rod inner segments, and with $\mathrm{K}_{V} 2.1$ and $\mathrm{K}_{V} 2.2$ in cone inner segments in human retina. $\mathrm{K}_{V} 8.2$ interacts with both $\mathrm{K}_{\mathrm{V}} 2$ subunits in macaque retinal lysates and $\mathrm{K}_{V} 2.1$ protein is less phosphorylated in retina than in cortical lysates. Finally, we describe two distinct $\mathrm{K}_{\mathrm{V}}$ currents in rods and cones; a high-voltage-activated current sensitive to GxTX-1E and citalopram that likely arises from homomeric $\mathrm{K}_{\mathrm{V}} 2$ channels; and a low-voltage-activated current that is resistant to these agents and may arise from $\mathrm{K}_{\mathrm{V}} 2 / \mathrm{K}_{\mathrm{V}} 8.2$ heteromeric channels.

\section{$\mathrm{K}_{\mathrm{V}} 2$ and $\mathrm{K}_{\mathrm{V}} 8$ channels in photoreceptors}

Figure 11 summarizes the localization of the $\mathrm{K}_{\mathrm{V}} 2$ and $\mathrm{K}_{\mathrm{V}} 8.2$ channel subunits. Our findings extend upon previous studies showing $\mathrm{K}_{\mathrm{V}} 8.2$ and $\mathrm{K}_{\mathrm{V}} 2.1$ gene expression in human (Wu et al., 2006), rat (Hölter et al., 2012), and mouse (Czirják et al., 2007) retina. In agreement with our findings, $\mathrm{K}_{\mathrm{V}} 2.1$ protein has been localized to mouse photoreceptor inner segments (Pinto and Klumpp, 1998) and $\mathrm{K}_{\mathrm{V}} 2.2$ protein is present in developing Xenopus retina (Gravagna et al., 2008). Interestingly, the genes encoding $K_{V} 8.2$ and $\mathrm{K}_{\mathrm{V}} 2.1$ are subject to circadian modulation, showing increased levels during nocturnal hours in rat retina (Hölter et al., 2012). We speculate that such changes in $\mathrm{K}_{\mathrm{V}} 8.2$ levels could lead to dynamic modulation of $\mathrm{K}_{\mathrm{V}} 2$ currents under different physiological conditions. In addition to cyclical changes in gene expression, further dynamic modulation could arise through variable phosphorylation of channel subunits, especially for $\mathrm{K}_{\mathrm{V}} 2.1$.

We showed lower levels of $K_{V} 2.2$ protein in $S$ cones than in $\mathrm{L} / \mathrm{M}$ cones. Although we did not attempt to differentiate cone types in our functional recordings, lower levels of $\mathrm{K}_{\mathrm{V}} 2.2$ might be expected to alter the temporal response properties of $\mathrm{S}$ cones. A recent study in goldfish retina showed that $S$ cones have smaller $I_{h}$ currents than L/M cones, a difference that slows the voltage re- sponses of S cones despite both cone types having comparable photocurrent kinetics (Howlett et al., 2017). Together, these data indicate that differences in voltage-gated ion channel expression distinguish $\mathrm{S}$ cones from $\mathrm{L} / \mathrm{M}$ cones, furthering evidence for molecular differences between cone types (for review, see Calkins, 2001).

\section{Implications for normal photoreceptor function}

We have described a $K_{V}$ current that activates with a $V_{1 / 2}$ of $\sim-48 \mathrm{mV}$ in rods and $\mathrm{a}_{1 / 2}$ of $\sim-55 \mathrm{mV}$ in cones. The rod current is similar to that described previously in salamander rods $\left(\mathrm{V}_{1 / 2}\right.$ of $\sim-46.4 \mathrm{mV}$ ) (Beech and Barnes, 1989). The more negative activation of the cone $\mathrm{K}_{\mathrm{V}}$ current aligns with the relatively more hyperpolarized operating range of macaque cones $(\sim-46$ to $-58 \mathrm{mV}$ cones, $\sim-37$ to $-55 \mathrm{mV}$ rods, see Schneeweis and Schnapf, 1995). The observed difference in activation between rods and cones might be accounted for by inclusion of the $\mathrm{K}_{\mathrm{V}} 2.2$ subunit in cones; indeed, in expression systems, $\mathrm{K}_{\mathrm{V}} 2.2$ homomers exhibit relatively more hyperpolarized activation potentials ( $\sim-7 \mathrm{mV}$ shift) than homomeric $\mathrm{K}_{\mathrm{V}} 2.1$ channels (but see Kihira et al., 2010; Bishop et al., 2015).

Two other $\mathrm{K}_{\mathrm{V}}$ types have been proposed to underlie $\mathrm{I}_{\mathrm{Kx}}-\mathrm{K}_{\mathrm{V}} 7$ (M-type) channels (Zhang et al., 2011) and ether-à-go-go (EAG) channels (Frings et al., 1998). The lack of effect of a selective blocker of $\mathrm{K}_{\mathrm{V}} 7$ channels would seem to rule out a major role for these channels in producing $\mathrm{I}_{\mathrm{Kx}}$ in monkey photoreceptors. Although EAG channels have been localized to bovine photoreceptors by ISH (Frings et al., 1998), they seem unlikely to mediate the $\mathrm{I}_{\mathrm{Kx}}$ current because $\mathrm{Ba}^{2+}$ produces strong inactivation and suppression of EAG currents without altering the voltage dependence of activation. By contrast, $\mathrm{Ba}^{2+}$ does not block the low-voltage-activated currents described here but causes a depolarizing shift in activation potential. EAG currents also deactivate much faster than $\mathrm{I}_{\mathrm{Kx}}(<10 \mathrm{~ms}$ vs $\sim 100 \mathrm{~ms}$ at $-40 \mathrm{mV})$ (Frings et al., 1998).

The peptide toxins, stromatoxin-1 and GxTX-1E, block expressed homomeric $\mathrm{K}_{\mathrm{V}} 2.1$ and $\mathrm{K}_{\mathrm{V}} 2.2$ channels (Escoubas et al., 2002), and native channels in some central neurons (Speca et al., 2014; e.g., Liu and 
A
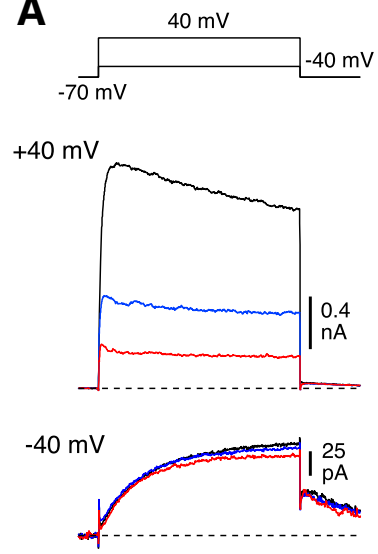

C
B

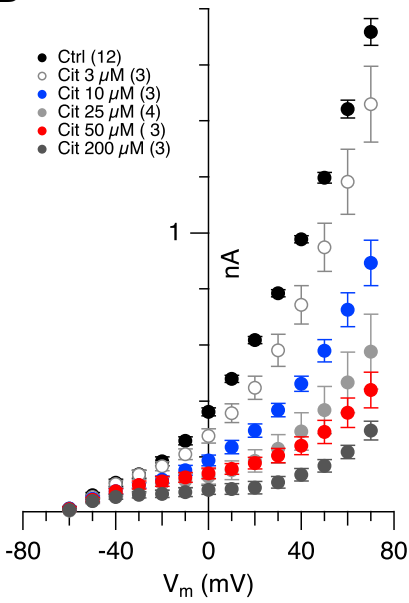

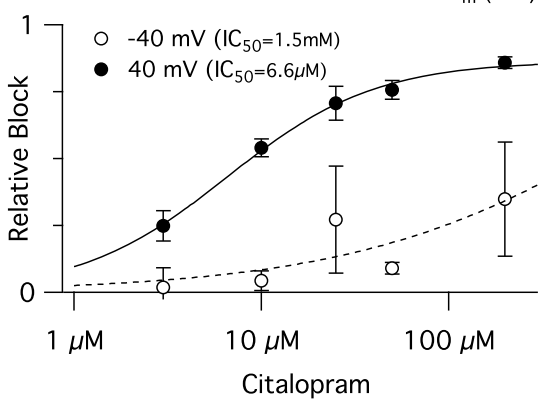

Figure 10. Citalopram blocks a high-voltage-activated current in cones. $A$, Representative voltage-gated currents before (black trace) and after application of $10 \mu \mathrm{m}$ (blue traces) or 50 $\mu \mathrm{M}$ (red traces) citalopram. The measurement time was $450 \mathrm{~ms}$ after the onset of a $500 \mathrm{~ms}$ voltage step. Note the suppressive effect of citalopram only for the more depolarized step potential. $\boldsymbol{B}$, Average ( \pm SEM) voltage-gated currents in response to a series of $500 \mathrm{~ms}$ voltage steps from a holding potential of $-70 \mathrm{mV}$ in control solution (Ctrl-CoCs Ames') or after wash-in of increasing concentrations of citalopram. The number of cells tested for each concentration is shown in parentheses. C, Dose-response curve showing relative block of citalopram at a test potential of $-40 \mathrm{mV}$ (open circles) or $40 \mathrm{mV}$. Data points were fitted using the Hill equation.

Bean, 2014; Bishop et al., 2015; Kimm et al., 2015). However, stromatoxin-1 had no effect on MNTB neurons, which are known to express $\mathrm{K}_{\mathrm{V}} 2$ channels (Johnston et al., 2008). These variable pharmacological effects might be accounted for by the presence of modifier subunits, which can reduce the sensitivity for GxTX-1E compared with homomeric $\mathrm{K}_{\mathrm{V}} 2.1$ channels (MorenoDomínguez et al., 2009). These findings suggest that the low-voltage-activated GxTX-1E-insensitive current in photoreceptors could arise from heteromeric $\mathrm{K}_{\mathrm{V}} 2 / \mathrm{K}_{\mathrm{V}} 8.2$ channel complexes, but we cannot exclude the involvement of another type of $\mathrm{Kv}$ channel. The high-voltage-activated current component, which was sensitive to GxTX-1E and citalopram, very likely originates from homomeric $\mathrm{K}_{\mathrm{V}} 2$ channels.

In other central neurons, homomeric $\mathrm{K}_{\mathrm{V}} 2$ channels activate at potentials positive to $\sim-40 \mathrm{mV}$; thus, while they play important roles in spiking neurons, they would be expected to contribute little current over the photoreceptor operating range. There are several features of photoreceptor $\mathrm{K}_{\mathrm{V}} 2$ channels that could shift the voltage dependence of activation to more hyperpolarized potentials. First, the presence of $K_{V} 8.2$ can induce a negative shift in the activation threshold for $\mathrm{K}_{\mathrm{V}} 2$ channels by $\sim 20 \mathrm{mV}$ in oocytes (Czirják et al., 2007), although this shift is not observed in HEK293 cells, suggesting that the native environment may influence channel gating. Second, the diffuse localization of $\mathrm{K}_{\mathrm{V}} 2.1$ in photoreceptor membranes and the small electrophoretic shift of $\mathrm{K}_{\mathrm{V}} 2.1$

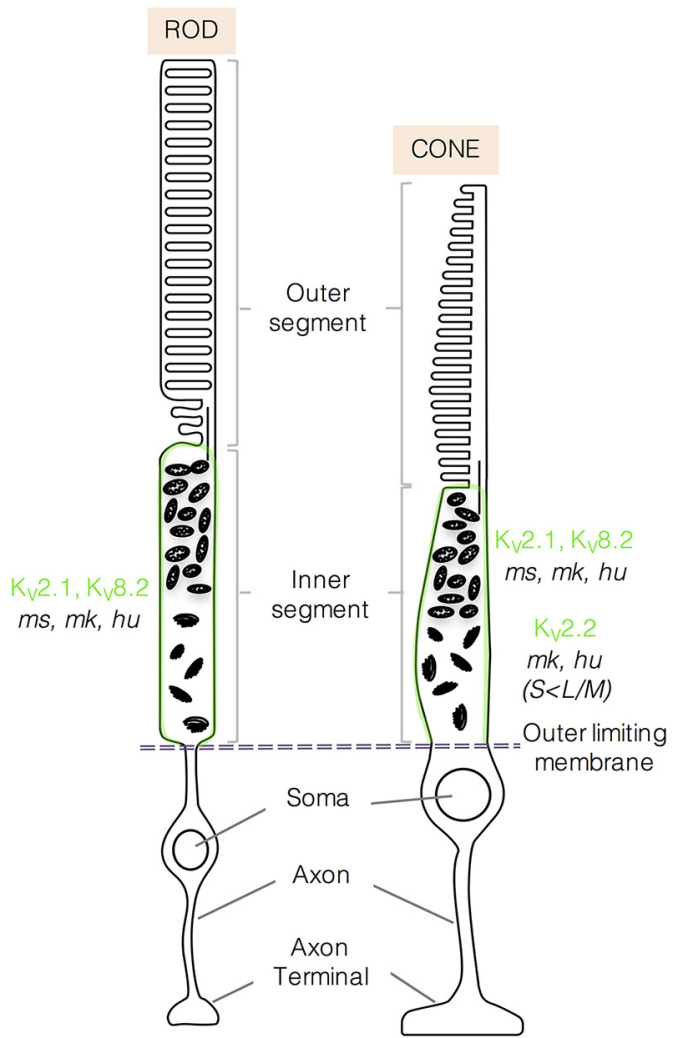

Figure 11. Schematic diagram summarizing the localization of $K_{V} 2$ and $K_{V} 8.2$ channel subunits in mouse and primate retina. Green shading represents the region where $K_{V}$ channel subunits are concentrated. ms, Mouse; mk, macaque; hu, human.

with phosphatase treatment suggest that $\mathrm{K}_{\mathrm{V}} 2.1$ is less phosphorylated in retina than in cortical neurons. Upon dephosphorylation, $\mathrm{K}_{\mathrm{V}} 2.1$ channels decluster and the $\mathrm{V}_{1 / 2}$ for activation can shift by up to $-35 \mathrm{mV}$ (Murakoshi et al., 1997; Park et al., 2006). The recent discovery of complexes comprised of $\mathrm{K}_{\mathrm{V}} 2.1$ subunits, $\mathrm{K}_{\mathrm{V}} 6.4$ (a modifier subunit) and the $\beta$ auxiliary subunit KCNE5, indicate diverse mechanisms for tailoring $\mathrm{K}_{\mathrm{V}} 2$ channel biophysical properties (David et al., 2015). In summary, the presence of the $\mathrm{K}_{\mathrm{V}} 8.2$ subunit and the hypophosphorylated state of retinal $\mathrm{K}_{\mathrm{V}} 2.1$ could shift $\mathrm{K}_{\mathrm{V}} 2$ activation into the operating range of photoreceptors.

In response to dim light stimuli, the tonic $\mathrm{I}_{\mathrm{Kx}}$ current that is active at rest shuts off with a delay producing a depolarization that makes the voltage response more transient and bandpass filtered (Beech and Barnes, 1989; Barrow and Wu, 2009). With brighter flash intensities, an $\mathrm{I}_{\mathrm{h}}$ current also activates exerting a similar depolarizing effect (Cangiano et al., 2007; Barrow and Wu, 2009; Della Santina et al., 2012). In oocytes that express $K_{V} 2.1 / K_{V} 8.2$, a similar filtering effect is observed when cells are injected with current to simulate the light response (Czirják et al., 2007). Together, the $\mathrm{K}_{\mathrm{V}} 2.1 / \mathrm{K}_{\mathrm{V}} 8.2$ is a strong candidate for mediating the low-voltageactivated $\mathrm{I}_{\mathrm{Kx}}$ current in primate photoreceptors.

\section{Implications for KCNV2 cone-rod dystrophy}

Patients with KCNV2 mutations exhibit deficits in rod-, L/M-, and $\mathrm{S}$ cone-mediated responses (Stockman et al., 2014), although subjective reports of night blindness vary across subjects (Robson et al., 2010; Zobor et al., 2012). Despite these widespread functional deficits, gross degenerative changes appear to be restricted to the macula region (Sergouniotis et al., 2012; Zobor et al., 2012), 
suggesting that KCNV2 mutations might differentially impact rod and cone survival.

KCNV2 mutations affect different parts of the protein with varying consequences. For example, pore domain mutations in $\mathrm{K}_{\mathrm{V}} 8.2$ impair conduction of $\mathrm{K}_{\mathrm{V}} 2.1 / \mathrm{K}_{\mathrm{V}} 8.2$ heteromers, whereas mutations in the tetramerization domain prevent heteromer formation, thus increasing the number of homomeric $\mathrm{K}_{\mathrm{V}} 2.1$ channels. Because homomeric $\mathrm{K}_{\mathrm{V}} 2.1$ channels show a higher level of steady-state inactivation than $\mathrm{K}_{\mathrm{V}} 2.1 / \mathrm{K}_{\mathrm{V}} 8.2$ heteromers (Smith et al., 2012) and are not activated at typical cone resting potentials, both types of mutations should reduce $\mathrm{I}_{\mathrm{K}}$ and depolarize the resting potential. This shift, in turn, could increase activation of L-type calcium channels and trigger calcium-dependent neurodegenerative mechanisms (Kulkarni et al., 2016). A depolarized resting membrane potential might also account for the pathognomonic electroretinogram (ERG) findings observed in patients with KCNV2 mutations. These individuals exhibit markedly reduced ERG amplitudes and temporal deficits for dim light stimuli, but "supernormal" or augmented ERG responses at brighter stimulus intensities (Gouras et al., 1983; Wissinger et al., 2008). A possible explanation is that loss of $\mathrm{I}_{\mathrm{Kx}}$ depolarizes the resting potential such that the voltage-gated calcium current no longer varies linearly with changes in light intensity. The result is that brighter stimuli are required to shut off transmitter release; and when this threshold is reached, a "supernormal" postreceptoral response (b-wave) manifests in the ERG.

The initial negative deflection of the ERG (a-wave) originates from the light-induced hyperpolarization of photoreceptors. $\mathrm{Pa}-$ tients with KCNV2 mutations show a prolongation of the a-wave, which manifests as a broadened "trough." This ERG abnormality is consistent with the idea that $\mathrm{K}_{\mathrm{V}} 2 / \mathrm{K}_{\mathrm{V}} 8.2$ heteromeric channels contribute to the delayed depolarizing phase of the photovoltage response: with reduced or absent $\mathrm{K}_{\mathrm{V}}$ current deactivation, the light-induced photoreceptor hyperpolarization becomes more sustained. The marked deficits in photopic flicker sensitivity seen with ERG are also consistent with a role for $\mathrm{K}_{\mathrm{V}} 2 / \mathrm{K}_{\mathrm{V}} 8.2$ heteromeric channels in temporal signaling. Together, these findings support a central role for $\mathrm{K}_{\mathrm{V}} 2 / \mathrm{K}_{\mathrm{V}} 8.2$ channels in shaping the human photoreceptor voltage response.

\section{References}

Aslanidis A, Karlstetter M, Walczak Y, Jägle H, Langmann T (2014) RETINA-specific expression of Kcnv2 is controlled by cone-rod homeobox (Crx) and neural retinaleucine zipper (Nrl). Adv Exp Med Biol 801: 31-41. CrossRef Medline

Barnes S, Deschênes MC (1992) Contribution of Ca and Ca-activated Cl channels to regenerative depolarization and membrane bistability of cone photoreceptors. J Neurophysiol 68:745-755. CrossRef Medline

Barrow AJ, Wu SM (2009) Low-conductance HCN1 ion channels augment the frequency response of rod and cone photoreceptors. J Neurosci 29: 5841-5853. CrossRef Medline

Beech DJ, Barnes S (1989) Characterization of a voltage-gated $\mathrm{K}^{+}$channel that accelerates the rod response to dim light. Neuron 3:573-581. CrossRef Medline

Bishop HI, Guan D, Bocksteins E, Parajuli LK, Murray KD, Cobb MM, Misonou H, Zito K, Foehring RC, Trimmer JS (2015) Distinct cell- and layer-specific expression patterns and independent regulation of Kv2 channel subtypes in cortical pyramidal neurons. J Neurosci 35:1492214942. CrossRef Medline

Bocksteins E (2016) Kv5, Kv6, Kv8, and Kv9 subunits: no simple silent bystanders. J Gen Physiol 147:105-125. CrossRef Medline

Bocksteins E, Snyders DJ (2012) Electrically silent Kv subunits: their molecular and functional characteristics. Physiology (Bethesda) 27:73-84. CrossRef Medline

Calkins DJ (2001) Seeing with S cones. Prog Retin Eye Res 20:255-287. CrossRef Medline
Cangiano L, Gargini C, Della Santina L, Demontis GC, Cervetto L (2007) High-pass filtering of input signals by the Ih current in a non-spiking neuron, the retinal rod bipolar cell. PLoS One 2:e1327. CrossRef Medline

Cerda O, Trimmer JS (2011) Activity-dependent phosphorylation of neuronal Kv2.1 potassium channels by CDK5. J Biol Chem 286:28738-28748. CrossRef Medline

Chiquet C, Dkhissi-Benyahya O, Chounlamountri N, Szel A, Degrip WJ, Cooper HM (2002) Characterization of calbindin-positive cones in primates. Neuroscience 115:1323-1333. CrossRef Medline

Czirják G, Tóth ZE, Enyedi P (2007) Characterization of the heteromeric potassium channel formed by Kv2.1 and the retinal subunit Kv8.2 in Xenopus oocytes. J Neurophysiol 98:1213-1222. CrossRef Medline

David JP, Stas JI, Schmitt N, Bocksteins E (2015) Auxiliary KCNE subunits modulate both homotetrameric Kv2.1 and heterotetrameric Kv2.1/Kv6.4 channels. Sci Rep 5:12813. CrossRef Medline

Della Santina L, Piano I, Cangiano L, Caputo A, Ludwig A, Cervetto L, Gargini C (2012) Processing of retinal signals in normal and HCN deficient mice. PLoS One 7:e29812. CrossRef Medline

Escoubas P, Diochot S, Célérier ML, Nakajima T, Lazdunski M (2002) Novel tarantula toxins for subtypes of voltage-dependent potassium channels in the Kv2 and Kv4 subfamilies. Mol Pharmacol 62:48-57. CrossRef Medline

Frings S, Brüll N, Dzeja C, Angele A, Hagen V, Kaupp UB, Baumann A (1998) Characterization of ether-à-go-go channels present in photoreceptors reveals similarity to $\mathrm{IKx}, \mathrm{a} \mathrm{K}^{+}$current in rod inner segments. J Gen Physiol 111:583-599. CrossRef Medline

Gouras P, Eggers HM, MacKay CJ (1983) Cone dystrophy, nyctalopia, and supernormal rod responses: a new retinal degeneration. Arch Ophthalmol 101:718-724. CrossRef Medline

Gravagna NG, Knoeckel CS, Taylor AD, Hultgren BA, Ribera AB (2008) Localization of Kv2.2 protein in Xenopus laevis embryos and tadpoles. J Comp Neurol 510:508-524. CrossRef Medline

Guan D, Tkatch T, Surmeier DJ, Armstrong WE, Foehring RC (2007) Kv2 subunits underlie slowly inactivating potassium current in rat neocortical pyramidal neurons. J Physiol 581:941-960. CrossRef Medline

Herrington J, Zhou YP, Bugianesi RM, Dulski PM, Feng Y, Warren VA, Smith MM, Kohler MG, Garsky VM, Sanchez M, Wagner M, Raphaelli K, Banerjee P, Ahaghotu C, Wunderler D, Priest BT, Mehl JT, Garcia ML, McManus OB, Kaczorowski GJ, et al. (2006) Blockers of the delayedrectifier potassium current in pancreatic beta-cells enhance glucosedependent insulin secretion. Diabetes 55:1034-1042. CrossRef Medline

Hölter P, Kunst S, Wolloscheck T, Kelleher DK, Sticht C, Wolfrum U, Spessert R (2012) The retinal clock drives the expression of Kcnv2, a channel essential for visual function and cone survival. Invest Ophthalmol Vis Sci 53:6947-6954. CrossRef Medline

Howlett MH, Smith RG, Kamermans M (2017) A novel mechanism of cone photoreceptor adaptation. PLoS Biol 15:1-28. CrossRef Medline

Johnston J, Griffin SJ, Baker C, Skrzypiec A, Chernova T, Forsythe ID (2008) Initial segment Kv2.2 channels mediate a slow delayed rectifier and maintain high frequency action potential firing in medial nucleus of the trapezoid body neurons. J Physiol 586:3493-3509. CrossRef Medline

Jorge BS, Campbell CM, Miller AR, Rutter ED, Gurnett CA, Vanoye CG, George AL Jr, Kearney JA (2011) Voltage-gated potassium channel KCNV2 (Kv8.2) contributes to epilepsy susceptibility. Proc Natl Acad Sci U S A 108:5443-5448. CrossRef Medline

Kihira Y, Hermanstyne TO, Misonou H (2010) Formation of heteromeric Kv2 channels in mammalian brain neurons. J Biol Chem 285:1504815055. CrossRef Medline

Kimm T, Khaliq ZM, Bean BP (2015) Differential regulation of action potential shape and burst-frequency firing by BK and Kv2 channels in substantia nigra dopaminergic neurons. J Neurosci 35:16404-16417. CrossRef Medline

Kulkarni M, Trifunović D, Schubert T, Euler T, Paquet-Durand F (2016) Calcium dynamics change in degenerating cone photoreceptors. Hum Mol Genet 25:3729-3740. CrossRef Medline

Liu PW, Bean BP (2014) Kv2 channel regulation of action potential repolarization and firing patterns in superior cervical ganglion neurons and hippocampal CA1 pyramidal neurons. J Neurosci 34:4991-5002. CrossRef Medline

Misonou H, Mohapatra DP, Park EW, Leung V, Zhen D, Misonou K, Anderson AE, Trimmer JS (2004) Regulation of ion channel localization and phosphorylation by neuronal activity. Nat Neurosci 7:711-718. CrossRef Medline

Misonou H, Mohapatra DP, Trimmer JS (2005) Kv2.1: a voltage-gated $\mathrm{K}^{+}$ 
channel critical to dynamic control of neuronal excitability. Neurotoxicology 26:743-752. CrossRef Medline

Moreno-Domínguez A, Cidad P, Miguel-Velado E, López-López JR, PérezGarcía MT (2009) De novo expression of Kv6.3 contributes to changes in vascular smooth muscle cell excitability in a hypertensive mice strain. J Physiol 587:625-640. CrossRef Medline

Murakoshi H, Shi G, Scannevin RH, Trimmer JS (1997) Phosphorylation of the Kv2.1 $\mathrm{K}^{+}$channel alters voltage-dependent activation. Mol Pharmacol 52:821-828. CrossRef Medline

O’Connell KM, Loftus R, Tamkun MM (2010) Localization-dependent activity of the Kv2.1 delayed-rectifier $\mathrm{K}^{+}$channel. Proc Natl Acad Sci U S A 107:12351-12356. CrossRef Medline

O’Roak BJ, Vives L, Girirajan S, Karakoc E, Krumm N, Coe BP, Levy R, Ko A, Lee C, Smith JD, Turner EH, Stanaway IB, Vernot B, Malig M, Baker C, Reilly B, Akey JM, Borenstein E, Rieder MJ, Nickerson DA, et al. (2012) Sporadic autism exomes reveal a highly interconnected protein network of de novo mutations. Nature 485:246-250. CrossRef Medline

Ottschytsch N, Raes A, Van Hoorick D, Snyders DJ (2002) Obligatory heterotetramerization of three previously uncharacterized Kv channel alphasubunits identified in the human genome. Proc Natl Acad Sci U S A 99: 7986-7991. CrossRef Medline

Park KS, Mohapatra DP, Misonou H, Trimmer JS (2006) Graded regulation of the Kv2.1 potassium channel by variable phosphorylation. Science 313: 976-979. CrossRef Medline

Pinto LH, Klumpp DJ (1998) Localization of potassium channels in the retina. Prog Retin Eye Res 17:207-230. CrossRef Medline

Puthussery T, Gayet-Primo J, Taylor WR (2011) Carbonic anhydraserelated protein VIII is expressed in rod bipolar cells and alters signaling at the rod bipolar to AII-amacrine cell synapse in the mammalian retina. Eur J Neurosci 34:1419-1431. CrossRef Medline

Puthussery T, Venkataramani S, Gayet-Primo J, Smith RG, Taylor WR (2013) NaV1.1 channels in axon initial segments of bipolar cells augment input to magnocellular visual pathways in the primate retina. J Neurosci 33:16045-16059. CrossRef Medline

Robson AG, Webster AR, Michaelides M, Downes SM, Cowing JA, Hunt DM, Moore AT, Holder GE (2010) Cone dystrophy with supernormal rod electroretinogram: a comprehensive genotype/phenotype study including fundus autofluorescence and extensive electrophysiology. Retina 30: 51-62. CrossRef Medline

Schneeweis DM, Schnapf JL (1995) Photovoltage of rods and cones in the macaque retina. Science 268:1053-1056. CrossRef Medline

Sergouniotis PI, Holder GE, Robson AG, Michaelides M, Webster AR, Moore AT (2012) High-resolution optical coherence tomography imaging in KCNV2 retinopathy. Br J Ophthalmol 96:213-217. CrossRef Medline

Smith KE, Wilkie SE, Tebbs-Warner JT, Jarvis BJ, Gallasch L, Stocker M, Hunt DM (2012) Functional analysis of missense mutations in Kv8.2 causing cone dystrophy with supernormal rod electroretinogram. J Biol Chem 287:43972-43983. CrossRef Medline

Speca DJ, Ogata G, Mandikian D, Bishop HI, Wiler SW, Eum K, Wenzel HJ,
Doisy ET, Matt L, Campi KL, Golub MS, Nerbonne JM, Hell JW, Trainor BC, Sack JT, Schwartzkroin PA, Trimmer JS (2014) Deletion of the Kv2.1 delayed rectifier potassium channel leads to neuronal and behavioral hyperexcitability. Genes Brain Behav 13:394-408. CrossRef Medline

Stockman A, Henning GB, Michaelides M, Moore AT, Webster AR, Cammack J, Ripamonti C (2014) Cone dystrophy with "supernormal" rod ERG: psychophysical testing shows comparable rod and cone temporal sensitivity losses with no gain in rod function. Invest Ophthalmol Vis Sci 55:832-840. CrossRef Medline

Wei W, Elstrott J, Feller MB (2010) Two-photon targeted recording of GFPexpressing neurons for light responses and live-cell imaging in the mouse retina. Nat Protoc 5:1347-1352. CrossRef Medline

Wissinger B, Dangel S, Jägle H, Hansen L, Baumann B, Rudolph G, Wolf C, Bonin M, Koeppen K, Ladewig T, Kohl S, Zrenner E, Rosenberg T (2008) Cone dystrophy with supernormal rod response is strictly associated with mutations in KCNV2. Invest Ophthalmol Vis Sci 49:751-757. CrossRef Medline

Wissinger B, Schaich S, Baumann B, Bonin M, Jägle H, Friedburg C, Varsányi B, Hoyng CB, Dollfus H, Heckenlively JR, Rosenberg T, Rudolph G, Kellner U, Salati R, Plomp A, De Baere E, Andrassi-Darida M, Sauer A, Wolf C, Zobor D, et al. (2011) Large deletions of the KCNV2 gene are common in patients with cone dystrophy with supernormal rod response. Hum Mutat 32:1398-1406. CrossRef Medline

Wu H, Cowing JA, Michaelides M, Wilkie SE, Jeffery G, Jenkins SA, Mester V, Bird AC, Robson AG, Holder GE, Moore AT, Hunt DM, Webster AR (2006) Mutations in the gene KCNV2 encoding a voltage-gated potassium channel subunit cause "cone dystrophy with supernormal rod electroretinogram" in humans. Am J Hum Genet 79:574-579. CrossRef Medline

Xu JW, Slaughter MM (2005) Large-conductance calcium-activated potassium channels facilitate transmitter release in salamander rod synapse. J Neurosci 25:7660-7668. CrossRef Medline

Yagi T, Macleish PR (1994) Ionic conductances of monkey solitary cone inner segments. J Neurophysiol 71:656-665. CrossRef Medline

Yan K, Matthews G (1992) Blockers of potassium channels reduce the outward dark current in rod photoreceptor inner segments. Vis Neurosci 8:479-481. CrossRef Medline

Zelinger L, Wissinger B, Eli D, Kohl S, Sharon D, Banin E (2013) Cone dystrophy with supernormal rod response: novel KCNV2 mutations in an underdiagnosed phenotype. Ophthalmology 120:2338-2343. CrossRef Medline

Zhan XQ, He YL, Yao JJ, Zhuang JL, Mei YA (2012) The antidepressant citalopram inhibits delayed rectifier outward $\mathrm{K}^{+}$current in mouse cortical neurons. J Neurosci Res 90:324-336. CrossRef Medline

Zhang X, Yang D, Hughes BA (2011) KCNQ5/Kv7.5 potassium channel expression and subcellular localization in primate retinal pigment epithelium and neural retina. Am J Physiol Cell Physiol 301:1017-1026. CrossRef Medline

Zobor D, Kohl S, Wissinger B, Zrenner E, Jägle H (2012) Rod and cone function in patients with KCNV2 retinopathy. PLoS One 7:e46762. CrossRef Medline 